\title{
Human Wildlife Conflicts in Southern Africa: Riding the Whirl Wind in Mozambique and in Zimbabwe
}

\author{
Sébastien Le Bel ${ }^{1}$, Amon Murwira ${ }^{2}$, Billy Mukamuri², \\ René Czudek ${ }^{3}$, Russell Taylor ${ }^{4}$ and Mike La Grange ${ }^{5}$ \\ ${ }^{1}$ Cirad (Centre de coopération internationale en recherche \\ agronomique pour le développement) \\ ${ }^{2}$ University of Zimbabwe \\ ${ }^{3} F A O$ Subregional Office for Southern Africa \\ ${ }^{4}$ WWF-Nambia \\ ${ }^{5}$ AWMC (African Wildlife Management and Conservation) \\ ${ }^{1}$ France \\ 2,3,5Zimbabwe \\ ${ }^{4}$ Namibia
}

\section{Introduction}

Human Wildlife Conflict (HWC) exists when the needs and behaviour of wildlife impact negatively on the goals of human beings (Cumming et al., 2007). It tends to manifest itself in scenarios where human strategies affect free movement of wild animals and vice versa. Thus, HWC can be considered inevitable in all communities where human and wildlife coexist and share the same habitat (Fig. 1).

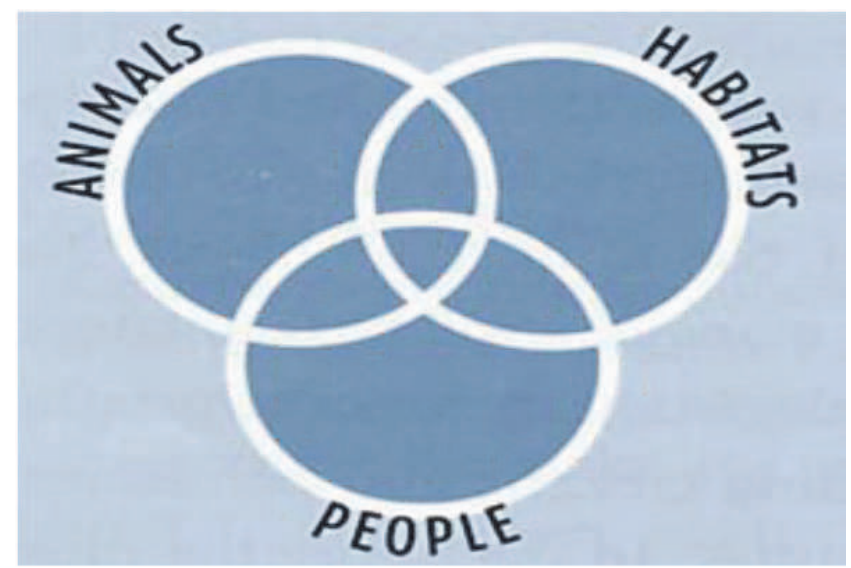

Fig. 1. People and Wildlife co-existence: a difficult equation 
HWC has an international magnitude even in urban areas (Breitenmoser et al., 2005; McGinnis, 2008) and a significant social impact which depends on the capacity of a community to support a certain level of conflicts (Woodroffe et al., 2005). In Africa, HWC is not restricted to a particular geographical region or climatic condition but is common in all areas where wildlife and human populations coexist and have limited resources (Distefano, 2004). The February 2010 meeting of the Southern African Development Community (SADC) Technical Committee on Wildlife pronounced that HWC was one of the main problems for Africa's rural populations in terms of personal security and economic loss, and the situation is getting worse (LeBel et al., 2010). The population of the African continent, which has the world's largest reserves of wildlife, is expected to double from 0.8 billion to 1.8 billion people in the next 40 years (ILRI, 2009). Africans will not only be packed more tightly into cities, they and their crops will also increasingly impinge upon territory populated by wildlife. The tragedy of HWC is in its dynamic; it can only be stopped by suppressing one of the two antagonists. All too often, affected communities and support agencies are engaged in a headlong rush with little visibility of what should be done and how.

The objective of this chapter is not to give a recipe of devices to solve all HWCs (e.g. problems of crop raiding elephants) or to give a roll map to NGO's in an attempt to reconcile hungry communities and free ranging mega-herbivores. As no blueprint or panacea exists, our philosophy is to explore options which will help rural communities to improve their capacity to live with problem animals. The principles developed though this chapter aim to increase human tolerance of wildlife species and to decrease negative interactions with them.

To achieve this, we will be referring to recent works conducted in Mozambique and in Zimbabwe, both countries who decided with the assistance of FAO (Food and Agriculture Organization of the United Nations) and AFD (Agence Française de Développement) to develop a national strategy to manage HWC.

The first section will point out key principles of HWC based on the example of Mozambique and specifically the case of Limpopo National Park. A focus on communities living in areas adjacent to national parks in Zimbabwe will help explain the depth of the HWC problem. A new approach, based on disease monitoring, is to invite communities to develop their own prevention strategies with the support of a HWC toolkit developed by BIO-HUB ${ }^{1}$ and FAO. The damages and problems associated with HWC have been high in areas adjacent to major National Parks. The improvement of alert systems allowing a quick and efficient control of problem animals will conclude this chapter.

\section{Co-existing with wildlife in Mozambique, a national problem}

Mozambique is a country located on the southeast coast of Africa with a total surface area of $801,590 \mathrm{~km}^{2}$. It is bound by Swaziland to the south, South Africa to the southwest, Zimbabwe to the west, Zambia and Malawi to the northwest, Tanzania to the north and the Indian Ocean to the east. The national population was recorded at 22 million in $2009 ; 80 \%$ of the Mozambican population live in rural areas where their livelihoods rely heavily on

${ }^{1}$ a consortium of CIRAD, IGF, IUCN-ROSA \& WWF-SARPO 
subsistence agriculture or fishing and on the use of natural resources; $45 \%$ of them (i.e. around 8 million people) have no access to water supply equipment and have to collect river water to meet their daily needs. In addition, about two hundred thousand people live in close contact with wildlife, either in the buffer zones or even within the protected areas. This explains the increasing incidence of HWC whose impact is exacerbated by the overall poverty prevailing in one of 10 poorest developing countries in the World.

\subsection{Human-wildlife conflict facts: National trends since 2006}

\subsubsection{National context}

HWC is not a new issue in Mozambique, but a dramatic increase in HWC cases has been noted in recent years with 265 people killed between July 2006 to September 2008 mostly by crocodile $(79 \%), 1,116$ ha destroyed in 2008 mainly by elephant $(86 \%)$ and hundreds of problem animals killed each year (Ministério da Agricultura, 2009).

In a response to the social impact of HWC, a national strategy to reduce HWC was developed and recently approved by the Government of Mozambique with the support of FAO. The Ministry of Agriculture (MINAG) is responsible for wildlife management outside protected areas and, since HWCs are more prone to succeed there, is in charge of the overall HWC management. More precisely HWC is managed by the Wildlife Department of the Directorate of Lands and Forests (DNTF) which has specifically appointed officers to manage this problem.

\subsubsection{Materials and methods}

DNTF started to collect HWC incident information from 1997. Between 1997 and 2003, a small data set of 34 records reported a few HWC cases in 9 of the 10 Mozambican provinces. During this period (1997-2003) 240 persons and 304 wild animals were killed; predominantly crocodile related attacks in Tete and Sofala provinces and man-eating lion attacks in Cabo Delgado Province (Anderson \& Pariela, 2005). The lack of data prevents any statistical analysis. Another set of 66 records was collected between 2004 and 2006. The absence of information on the timing (month), the location of the event (district) and the species involved in HWC make any analysis futile.

The available database is a set of HWC monthly reports compiled by DNTF from 2006 to 2010; data was only partially recorded during 2006 and 3 months of 2008 are missing (October, November and December).

The following analyses are based on 1,141 monthly incidents recorded. The XLSTAT software package was used to analyse the data. Data are presented as mean \pm SE. In order to test for independence between percentages of measured variables, the Pearson's Chi-square test was used. The null-hypothesis between classes was rejected at $\mathrm{P}<0.05$ and results with $\mathrm{P}<0.001$ were considered highly significant. With the assumption that HWC events are strongly related to the presence of specific wild species in certain area at a certain time, a Multiple Correspondence Analysis (MCA) was conducted to study the association between spatial and temporal factors.

\subsubsection{National trends}

\subsubsection{HWC everywhere but targeted sites}

The most affected provinces in Mozambique are Cabo Delgado and Gaza which experienced 18\% of HWC incidents recorded between 2006 and 2010 (201 and 205 cases) followed by 
Manica, Maputo, Tete and Zambezia where $10 \%$ of incidents occurred during the same period (Fig. 2).

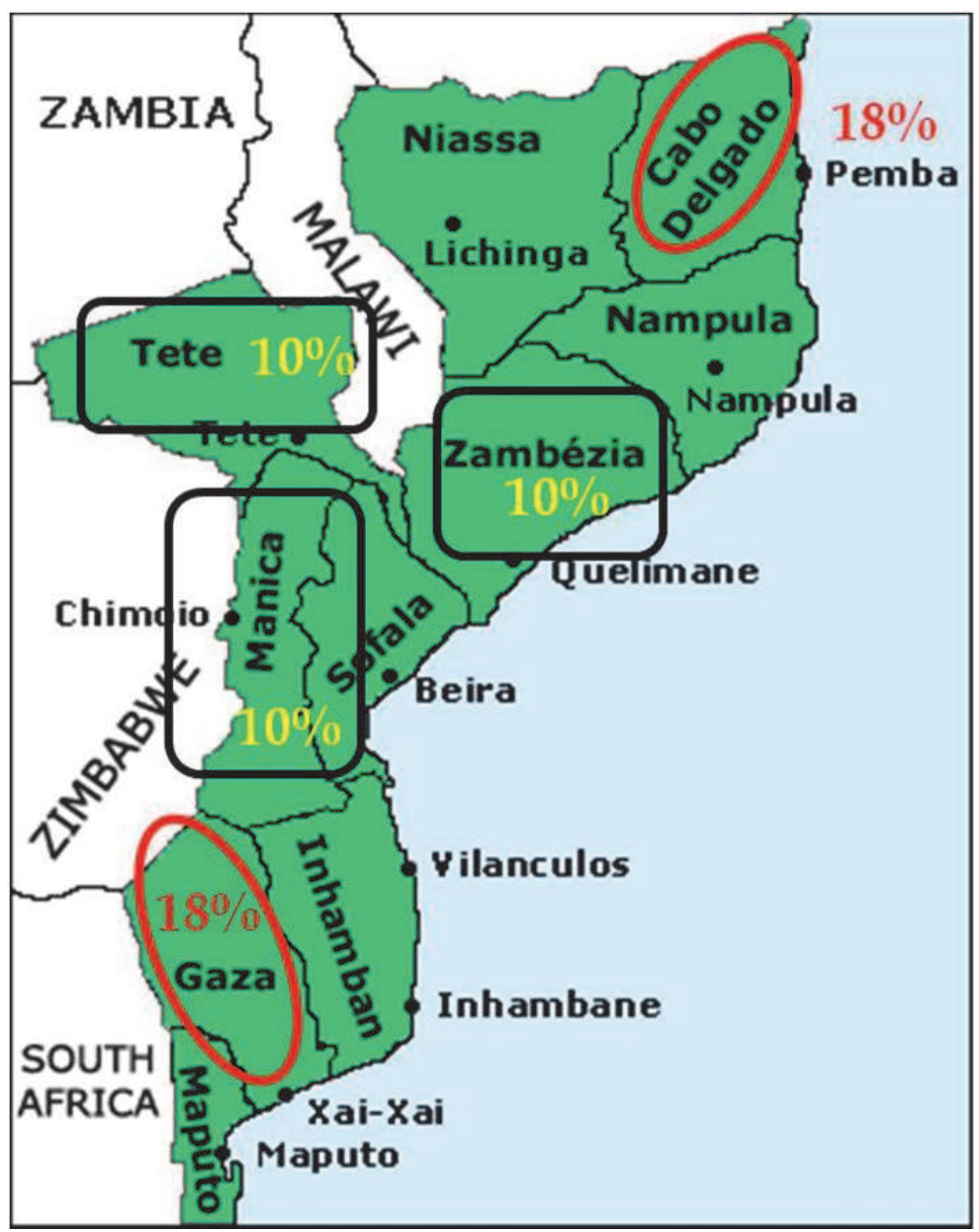

Fig. 2. HWC frequency per Province between 2006 and 2010

\subsubsection{An increasing problem all year long}

HWC appears to be an escalating problem, with reported cases increasing by a magnitude of 4.3 between 2006 and 2010 (Fig. 3). The frequency of HWC per month varies between 6 to $10 \%$ (Fig. 4) and occurs all year long with a similar incidence during the dry (51\%) and the rainy seasons (49\%). The risky months appear to be September and July (10\% of incidents reported) followed by March, April, June and October (8\% of HWC cases). 


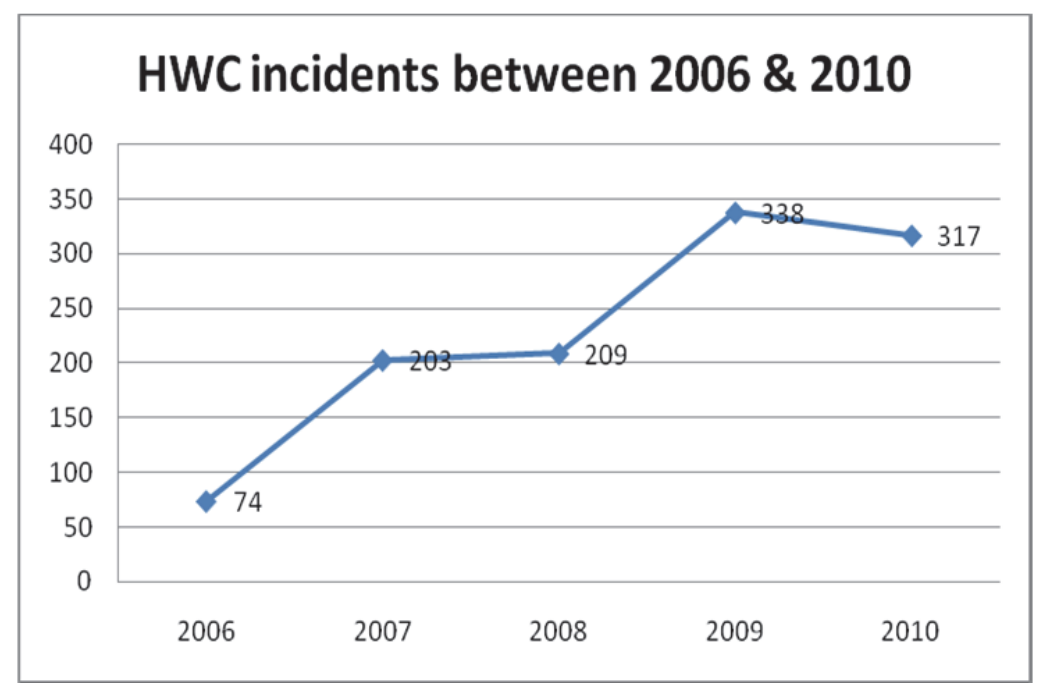

Fig. 3. Increase of HWCs between 2006 and 2010 in Mozambique

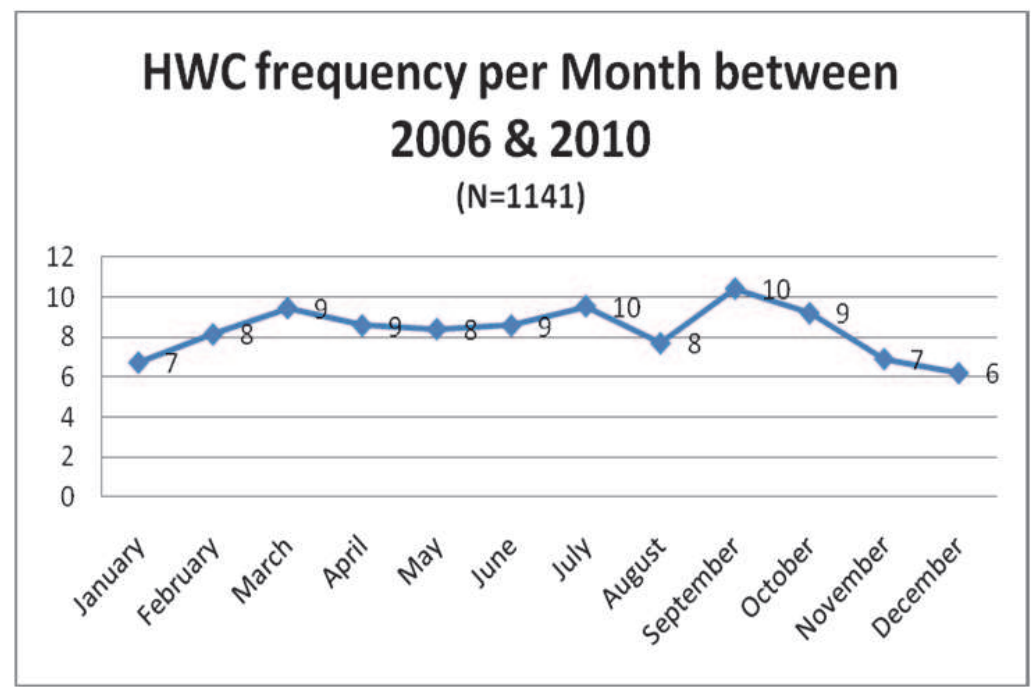

Fig. 4. Monthly frequency of HWC in Mozambique

\subsubsection{Mainly with elephant and crocodile}

Among the thirteen species involved in HWC between 2006 and 2010, four species predominated: elephant (39\% of the incidents) and crocodile $(29 \%)$ showed significantly more cases of attacks than hippopotamus and lion with respectively $16 \%$ and $10 \%$ of HWC records. The remaining species were occasionally involved in HWC with a few cases reported per year (Fig. 5). 


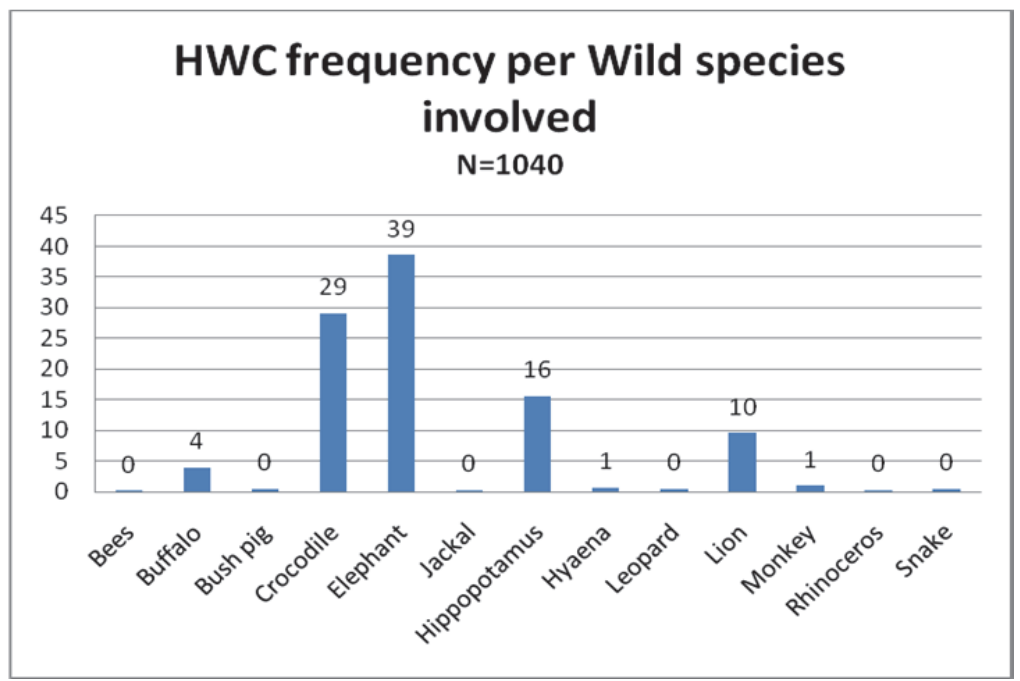

Fig. 5. Problem animals in Mozambique

A focus on the most affected six provinces reveals that elephants are the main problem animal with $41 \%$ of HWC recorded mainly in Cabo Delgado Province with $72 \%$ of HWC (Table 1). Species involvement is more balance in the other provinces except for Tete where crocodiles were the predominant species (54\%). Lion seem to be only a problem in Maputo Province with $24 \%$ of HWC. Observed differences are highly significant (Pearson ChiSquare=171, $\mathrm{df}=15, \mathrm{p}=0.001, \mathrm{n}=755$ ).

Wildlife involved in HWC

Province

\begin{tabular}{lccccccccc} 
& & Cabo & Gelgado & Gaza & Manica & Maputo Tete & Zambezia & Total \\
& & & & & & & \\
\hline Crocodile & Count (\%) & $20(12)$ & $49(28)$ & $37(35)$ & $25(25)$ & $44(39)$ & $51(54)$ & $226(30)$ \\
Elephant & Count $(\%)$ & $121(72)$ & $69(40)$ & $39(37)$ & $27(27)$ & $39(35)$ & $14(15)$ & $309(41)$ \\
Hippopo- & Count (\%) & $3(2)$ & $45(26)$ & $12(11)$ & $26(26)$ & $24(21)$ & $23(25)$ & $133(18)$ \\
tamus & Count (\%) & $24(14)$ & $11(6)$ & $17(16)$ & $24(24)$ & $5(5)$ & $6(6)$ & $87(12)$ \\
Lion & & 168 & 174 & 105 & 102 & 112 & 94 & 755 \\
Count & &
\end{tabular}

Table 1. HWC frequencies per wildlife species and province between 2006 and 2010

\subsubsection{A significant impact}

During this period 281 reports were generated for a total of 431 people being killed by a wild animal. This represented $25 \%$ of HWC incidents $(281 / 1141)$. The number of people being injured during the same period was less, with 106 reports (9\% of HWC incidents) for a total of 169 injured. When grouping people killed and injured as human casualties, the crocodile results in the greatest number of incidents with $61 \%$ of them (216), followed by the elephant with $21 \%$ (73), hippopotamus with $7 \%$ (25) and lion with $5 \%$ of the people being killed or injured (17). Observed differences are highly significant (Pearson Chi-square $=349$, $\mathrm{df}=13, \mathrm{p}=0.001, \mathrm{n}=1146)$. 
Between 2006 and 2010, 97 attacks against various domestic animals were recorded: cattle $(44 \%)$, goat $(35 \%)$, sheep, donkey, dog and chicken. A total of 807 individual animals were preyed upon, mainly by lion (58\%), crocodile (33\%) and hyena (4\%). Observed differences are highly significant (Pearson Ch-square $=433, \mathrm{df}=13, \mathrm{p}=0.001, \mathrm{n}=1146$ ).

Almost $25 \mathrm{~km}^{2}$ of crop were destroyed between 2006 and 2010 with an average of $11 \pm 2$ ha per monthly incident reported $(n=238)$. A total of 60 ha were destroyed in 2006, 962 ha in 2008 followed by 620 ha in 2010 (Fig. 6).

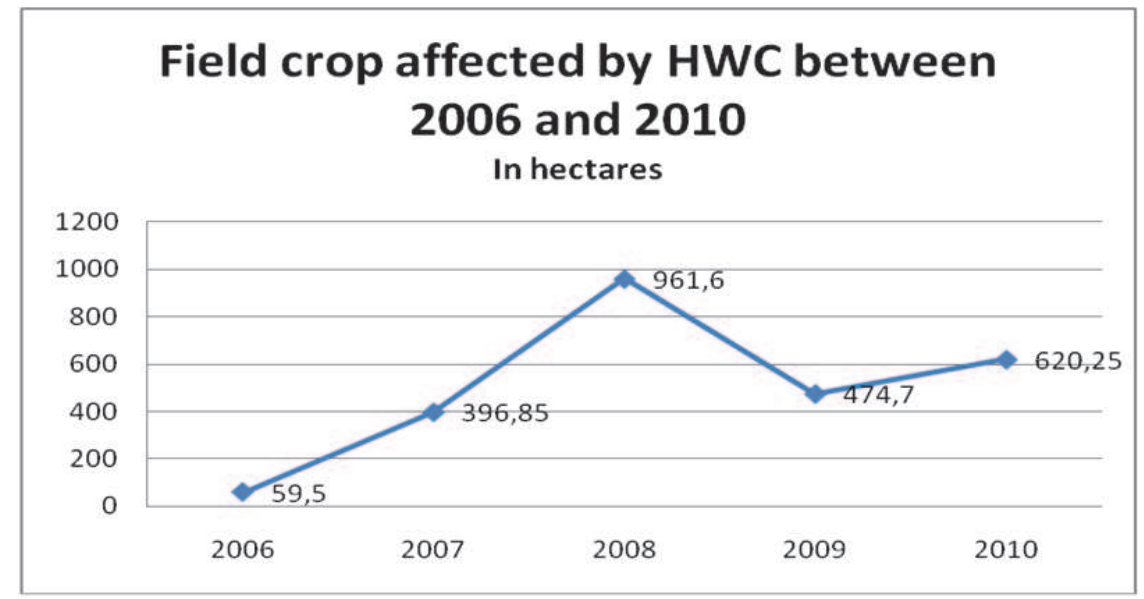

Fig. 6. Crops raids impact from 2006 to 2010

Four hundred and thirty five $(n=435)$ cases of field crop destruction were recorded but for $44 \%$ of them the levels of damage were not estimated. In two thirds of the cases $(65 \%)$ elephant was the species involved, followed by hippopotamus $(26 \%)$ and buffalo $(3 \%)$. Differences observed are highly significant (Pearson Chi-square $=532, d f=13, p=0,001$, $\mathrm{n}=1146)$.

During the study period, a few observations $(n=29)$ indicate that houses were targeted $(42 \%)$, granaries $(19 \%)$, canoes $(10 \%)$ and so-called properties $(10 \%)$. In most cases $(68 \%)$ elephants were responsible for the damages, followed by hippopotamus (13\%) and crocodile $(10 \%)$. Differences observed are highly significant (Pearson Chi-square $=35, \mathrm{df}=13, \mathrm{p}=0,001$, $\mathrm{n}=1146)$.

\subsubsection{Killing problem animals as the main mitigation strategy}

Monitoring (38\%) and killing (36\%) were the two most popular methods employed to deal with HWC (Table 2). Killing problem animals occurred mainly in Maputo (55\%), Zambezia $(42 \%)$ and Cabo Delgado (39\%) provinces. This usually relates to a single animal $(75 \%, \mathrm{n}=365)$ and these were listed as: elephant $(38 \%, 137)$, hippopotamus $(24 \%$, $86)$, crocodile $(23 \%, 82)$, lion $(7 \%, 26)$ and buffalo $(7 \%, 24)$. Between 2006 and 2010, 574 problem animals were destroyed, mostly elephants (33\%), crocodiles (29\%), hippopotamus $(20 \%)$ and lions $(7 \%)$. Note that the "No reaction" strategy significantly occured in $18 \%$ of cases and that the "Awareness" is a marginal strategy only implemented in Cabo Delgado $(1,2 \%)$. Observed differences are highly significant (Pearson Chi-Square $=65, \mathrm{df}=25, \mathrm{p}=0.001, \mathrm{n}=755$ ). 


\begin{tabular}{|c|c|c|c|c|c|c|c|c|}
\hline \multirow{2}{*}{\multicolumn{2}{|c|}{ Mitigation measures }} & \multicolumn{6}{|c|}{ Province } & \multirow[b]{2}{*}{ Total } \\
\hline & & $\begin{array}{c}\text { Cabo } \\
\text { Delgado }\end{array}$ & Gaza & Manica & Maputo & Tete & Zambezia & \\
\hline Awareness & $\begin{array}{c}\text { Count } \\
(\%)\end{array}$ & $2(1)$ & 0 & 0 & 0 & 0 & 0 & $2(<1)$ \\
\hline Chasing & $\begin{array}{c}\text { Count } \\
(\%)\end{array}$ & $4(2)$ & $10(6)$ & $4(4)$ & $4(4)$ & $4(4)$ & $6(6)$ & $32(4)$ \\
\hline Shooting & $\begin{array}{c}\text { Count } \\
(\%)\end{array}$ & $12(7)$ & $5(3)$ & 0 & 0 & $6(5)$ & $1(1)$ & $24(3)$ \\
\hline Killing & $\begin{array}{c}\text { Count } \\
(\%)\end{array}$ & $66(40)$ & $50(29)$ & $25(24)$ & $56(55)$ & $39(35)$ & $39(42)$ & $275(36)$ \\
\hline Monitoring & $\begin{array}{c}\text { Count } \\
(\%)\end{array}$ & $54(32)$ & $74(43)$ & $59(56)$ & $24(24)$ & $46(41)$ & $32(34)$ & $289(38)$ \\
\hline $\begin{array}{l}\text { No } \\
\text { reaction }\end{array}$ & $\begin{array}{c}\text { Count } \\
(\%)\end{array}$ & $30(18)$ & $35(20)$ & $17(16)$ & $18(18)$ & $17(15)$ & $16(17)$ & $133(18)$ \\
\hline Count & & 168 & 174 & 105 & 102 & 112 & 94 & 755 \\
\hline
\end{tabular}

Table 2. Frequencies of mitigation measures implemented per Province between 2006 and 2010

\subsubsection{HWC typology}

With the 5 main species involved in HWC and the 6 most affected provinces, a Multiple Correspondence Analysis (MCA) was conducted to study the association between spatial and temporal factors. The first four factors are predominating represent $72 \%$ of the variance. The major axis F1 explaining 49\% of variation is characterised by elephant being a major problem animal and Cabo Delgado in one direction, versus Zambezia Province and with crocodile and hippopotamus as the main dangerous species. The second axis F2 explaining $10 \%$ of the variation is characterized on one direction by Tete with elephant and crocodile, versus Maputo and lion (Table 3).

\begin{tabular}{lcc}
\hline & F1 & F2 \\
\hline Cabo Delgado & $\mathbf{2 0 , 4 6 3}$ & 1,673 \\
Gaza & $-4,745$ & 2,404 \\
Manica & 0,454 & $-3,062$ \\
Maputo & $-3,260$ & $-18,955$ \\
Tete & $-3,762$ & 12,497 \\
Zambezia & $\mathbf{- 1 2 , 7 7 8}$ & $\mathbf{4 , 2 0 7}$ \\
\hline DryS & $\mathbf{5 , 0 1 7}$ & $\mathbf{6 , 0 6 6}$ \\
RainyS & $\mathbf{- 5 , 0 1 7}$ & $\mathbf{- 6 , 0 6 6}$ \\
\hline Crocodile & $\mathbf{- 1 4 , 9 6 5}$ & $\mathbf{6 , 1 3 2}$ \\
Elephant & $\mathbf{2 0 , 4 1 9}$ & $\mathbf{8 , 3 6 7}$ \\
Hippopotamus & $\mathbf{- 1 1 , 9 9 1}$ & $\mathbf{- 2 , 2 8 1}$ \\
Lion & $\mathbf{4 , 3 2 7}$ & $\mathbf{- 1 8 , 9 5 7}$ \\
\hline
\end{tabular}

Table 3. Test values (Variables) The values displayed in bold are significant at the level alpha $=0.05$ 
The explanatory weight of the Variable Season is limited. Four types can be identified (Fig. 7.). The first two are very distinct:

- The Cabo Delgado type with elephant conflict and a slight influence of the dry season.

- The Maputo type with lion conflicts.

The last two are more complex, with more than one species involved:

- Zambezi type with crocodile and hippopotamus conflict.

- Tete type with crocodile and elephant conflict.

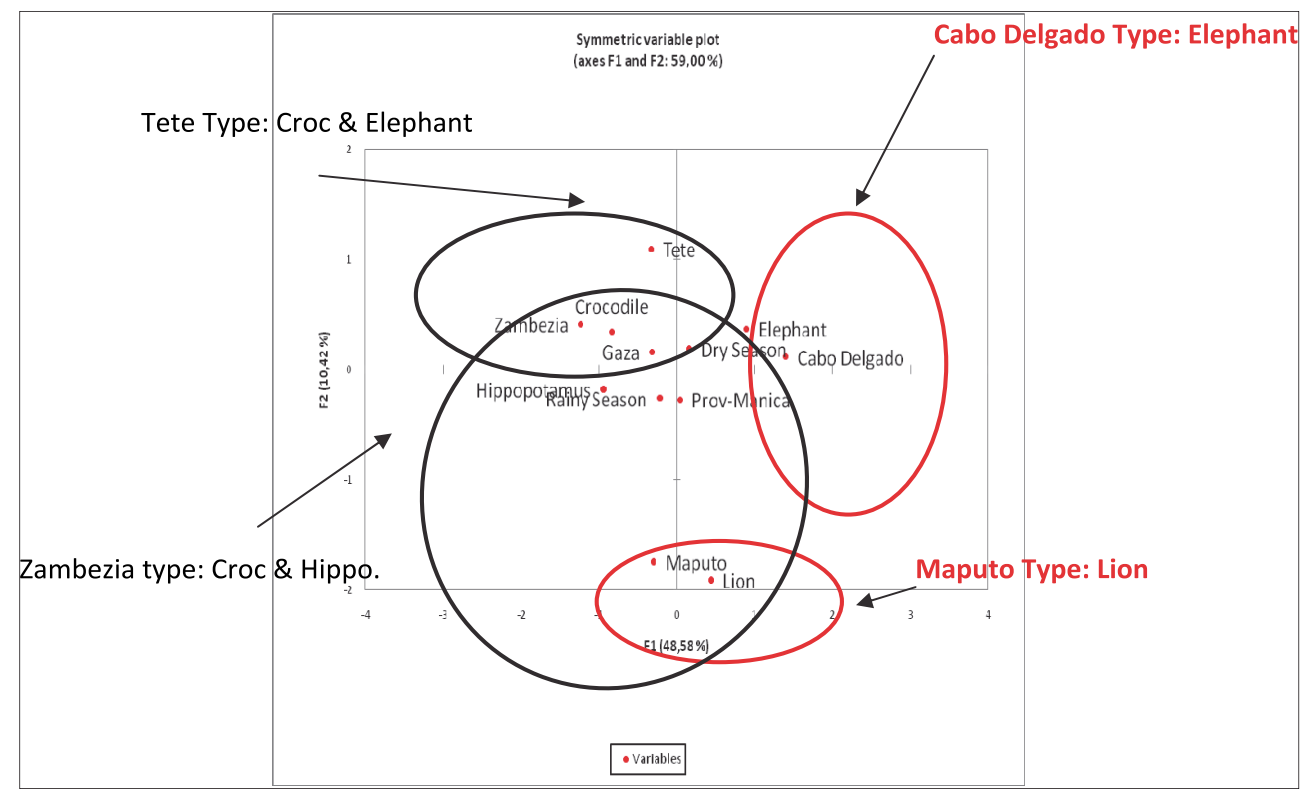

Fig. 7. Factorial plan for HWC data

\subsection{From fact to perception: The case of Limpopo National Park}

\subsubsection{A new born park: The Limpopo National Park}

The Coutada 16 (a hunting block) was proclaimed as the Limpopo National Park (LNP) in November 2001. The status of NP protects the land and prohibits human activities including prospecting and mining (Magane et al., 2003). On 9th December 2002, the presidents of South Africa, Mozambique and Zimbabwe signed the agreement on the establishment of the Great Limpopo Transfrontier Park (GLTP), and two days later the first $45 \mathrm{~km}$ of fencing between South Africa and Mozambique was removed. LNP is in the west of Gaza Province, adjacent with the international border with South Africa and to the south of the international border with Zimbabwe. Covering an area of $11,233 \mathrm{~km}^{2}$, LNP is part of the GLTP which includes the Kruger NP and Gonarezhou NP (Fig. 8).

The climate in LNP is subtropical with hot, wet summers and mild, dry winters $(360 \mathrm{~mm}$ in the north and $500 \mathrm{~mm}$ in the south). Rain occurs from September to April. The hydrology is characterized by 3 rivers which dictate the distribution of wildlife: the Limpopo and Elefantes rivers predominate, and to a lesser degree the Singwedzi which dries up in winter (Magane et al., 2003). 


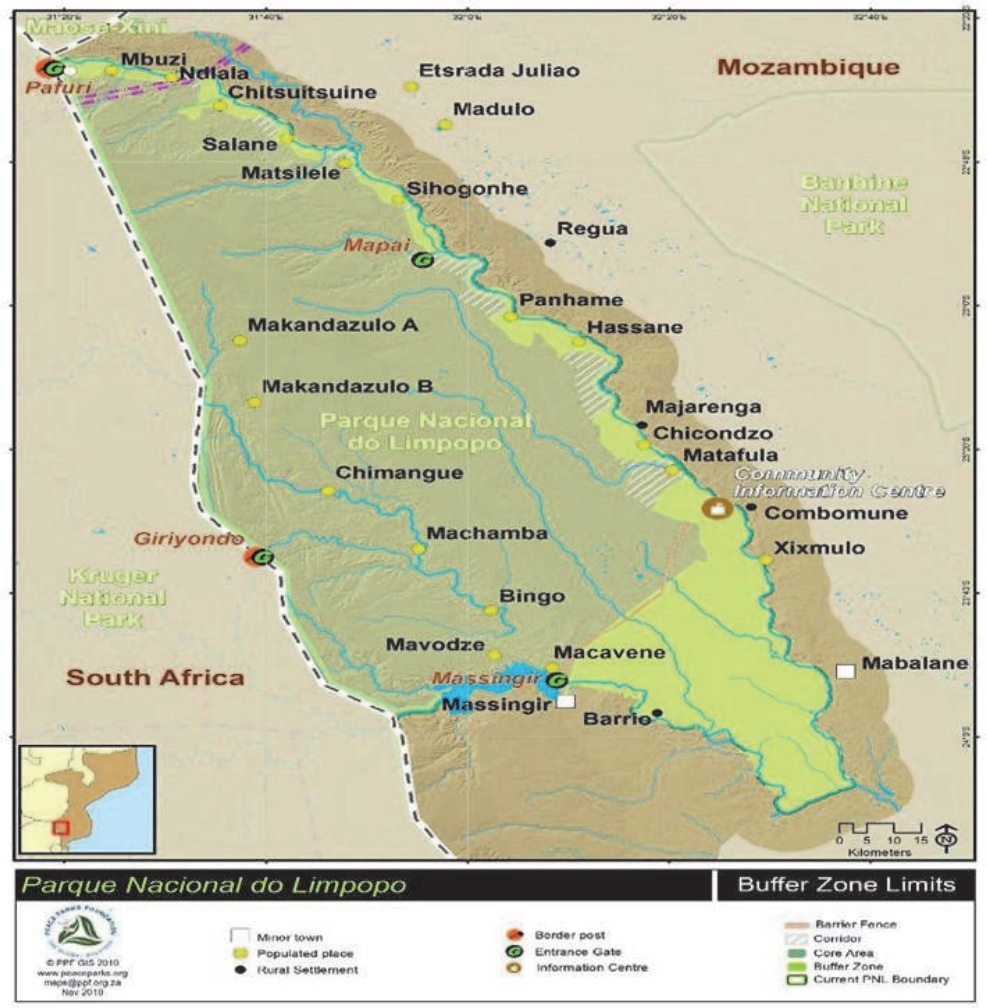

Fig. 8. Limpopo National Park limits

Mozambique's wildlife population was all but destroyed during the 14 years of war preceding 1990, and the country's parks have been battling to restore their game reserves ever since. About four thousand wild animals $(3,885)$ were translocated from Kruger National Park to LNP between 2001 and 2006 (Whyte \& Swanepol, 2006). Planes game included buffalo, hartebeest, impala, roan, waterbuck, wildebeest and zebra; megaherbivores included elephant (111 in 2001 and 2003), giraffe (61) and white rhino (12). From an area survey undertaken in 2006 covering most of the Shingwedzi River basin $\left(3,000 \mathrm{~km}^{2}\right)$, 630 elephant in sixty groups of 10.5 animals (mean size) were observed to be widely dispersed. This number greatly exceeded the number of elephants translocated to PNL suggesting that a natural re-colonization process had begun. All key problem animals exist in the area including the habitual crop raiders (elephant, buffalo, hippopotamus), livestock predators (lion, leopard, hyena, jackal) and man eaters (lion and crocodile). Densities are low but have been and will continue to be fueled by migration from Kruger National Park. No practical tool is in place or has been tested to monitor this population dynamic (density and movement).

The predominant tribe is the Shangaan. Approximately 4,350 inhabitants are living along the Shingwedzi River with about 5,200 head of cattle. A further 20,000 people live along the 
Limpopo and Elefantes rivers within the Buffer Zone of the Park. These people are distributed across 44 villages which consist of a total of 5,530 households. The support zone roughly extends on a $260 \mathrm{~km}$ straight line from Pafuri up to the junction with the Elefantes river and $65 \mathrm{~km}$ from the junction up to Chibotane; this gives an average distance of $7.4 \mathrm{~km}$ between each village. The population is expected to increase at an average rate of $2.6 \%$ per annum (Magane et al., 2003). Zoning is a management tool that delineates the Park into areas where developments of different type and scale are allowed, and where the levels of resource use and conservation inputs vary.

Communities are concerned with the Buffer Zone (BZ) of the park. The BZ should support both existing traditional subsistence livelihoods including crop and livestock agriculture, and sustainable economic development including opportunities for community-based tourism. The BZ extends westwards from the Limpopo River for a distance of $8-10 \mathrm{~km}$ and includes settlements and agricultural lands (crop and stock). Combining the land north of the confluence of the Limpopo and the Elefantes rivers and that between Massingir and Mabelane, this represents about $3,707 \mathrm{~km}^{2}$ (33\% of the LNP). The main activity is rain fed agriculture (maize, pumpkin and beans) complemented by raising livestock (Woodburne et al., 2002). Excepting the alluvial river banks, soils are poor and low unpredictable rains limit crop production. Trees are utilized for firewood, construction and production of charcoal and bushmeat is taken as an important source of protein. Cash income from employment is a rare occurrence (Magane et al., 2003). The dependence of the people on the natural resource base is increasing the potential conflicts between the people and the wild animals (Woodburne et al., 2002).

\subsubsection{Materials and methods}

A four day HWC training course was conducted in the south of LNP at a training centre in Massingir from the 5th - 8th of April 2011 then at the same period in the central of LNP at Mapai from the 11th - 14th of April. A total of 48 game rangers attended, 9 of them were dedicated HWC workers and 3 extension officers. The first day of the training was focused on gaining the game rangers perception of the current HWC situation. Their perceptions were extracted from a series of 13 questions using simple cards where they were asked to write their answers using one card per idea produced. The return given was good with a total of 1,116 cards produced ( 2 to 3 responses per question), giving an idea of the level of participation during the course. In parallel, the analyses of 384 incidents recorded by LNP between 2007 and 2010 allowed us to compare the perceptions of the game rangers with facts. The XLSTAT software package was used to analyze the data. Data are presented as mean \pm SE.

\subsubsection{Main findings}

\subsubsection{Key species involved in HWC}

The 384 HWC incidents between 2007 and 2010 reached a peak in 2008 with 144 cases (mean=96 per year). From HWC reports, the elephant was the main species involved in HWC with $83 \%$ of incidents. Game rangers also identified the elephant as the main problematic species but also mentioned the lion, buffalo, hippopotamus, crocodile and baboon as problem animals (Fig. 9). 


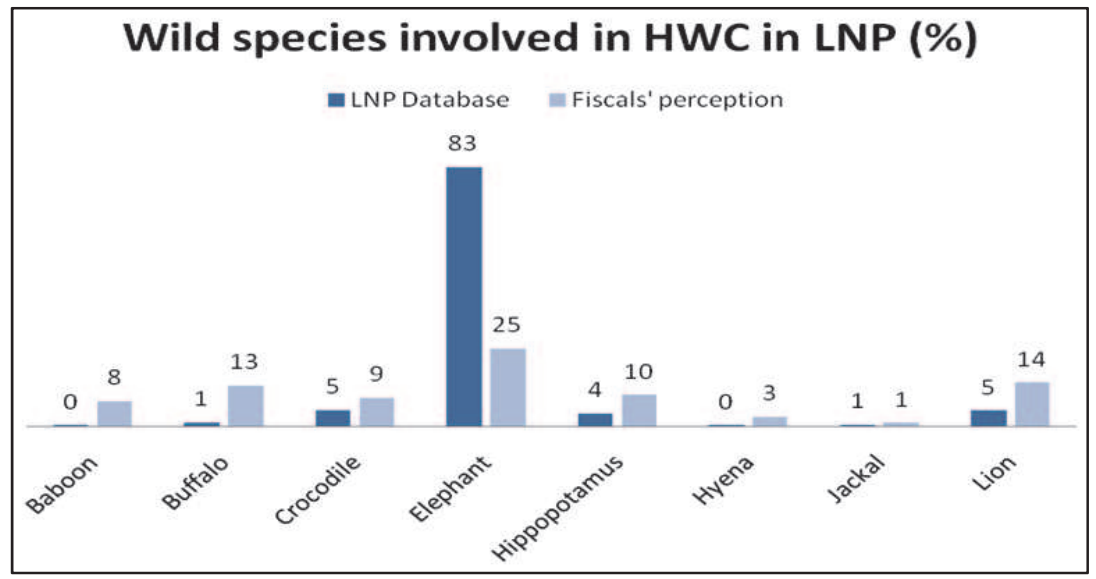

Fig. 9. Problem animals of $\mathrm{LNP}^{2}$

\subsubsection{Risky months}

When questioned "what are the risky months?" most of parks' staff mentioned January and March with 19\% of HWC incidents, followed by February and June with 13\% and 14\% of incidents. January to May, and also August are perceived as periods of elevated risk with a high prevalence of human-elephant conflict. June and July are dominated by lion conflicts. During the dry season (September to November), crocodiles are the main species involved and in December human-hippo conflicts predominate. When compared with the perception of the game rangers (fiscals), one can see that they are overestimating the occurrence of HWC during the first quarter and under-estimated during the second quarter of the year (Fig. 10).

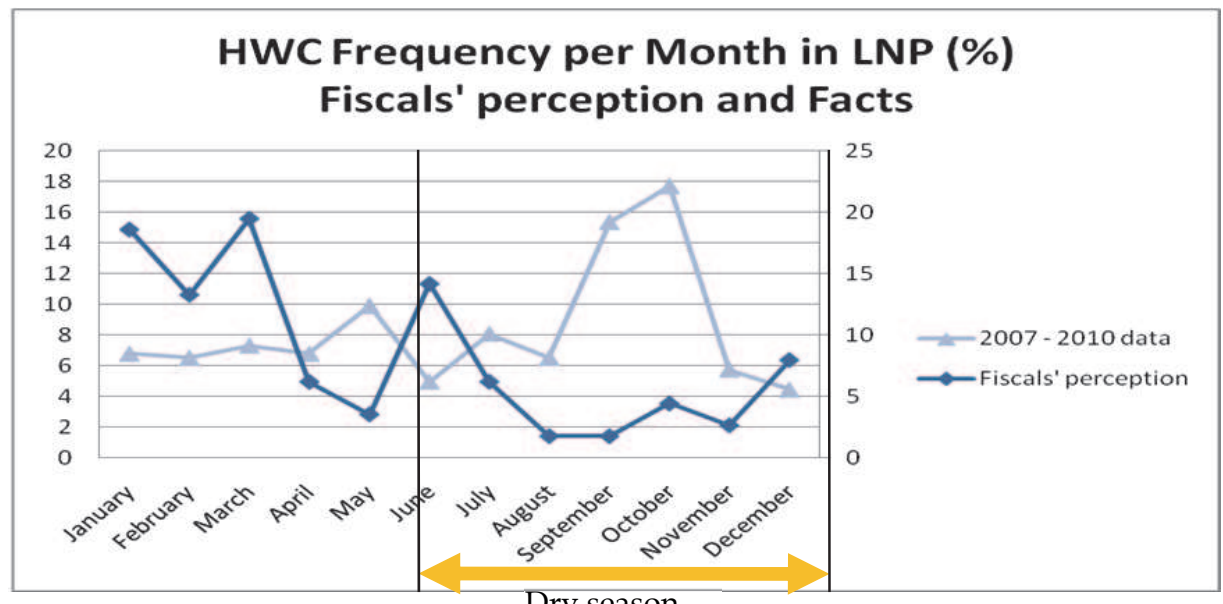

Dry season

Fig. 10. HWC has a strong seasonal pattern with $2 / 3$ of the incidents happening during the dry season $(n=384)$

2 "Fiscal" is the Portuguese name given to game scouts in Mozambique 


\subsubsection{Period of the day at most risk}

Night is perceived by the game rangers to be the most risky period of the day with a high frequency $(67 \%)$ of encountering dangerous animals. Human activity in the mornings and afternoons are also perceived as risky periods but with a smaller percentage of HWC $(14 \%)$. During the night the most dangerous animal is the elephant, during day time it is the crocodile.

\subsubsection{Localization of the hot spots of HWC in the Limpopo NP}

Using pins on a map the game rangers were asked to localize places mostly affected by HWC. Both groups from the North and South training courses indicated the triangle between the Limpopo and Elefantes Rivers (1), groups of villages close to the two pickets of Mapai and Pafuri (2) and villages along the Shingwedzi River (Fig. 11). The analysis of historical HWC incidents confirms that the southern part of the park with the District of Massingir is the most affected by HWC with 3/4 of incidents recorded between 2007 and 2010 (Fig. 12). More precisely 55\% of all HWC of LNP between 2007 and 2010 (212 incidents) were concentrated in 10 villages of this district.

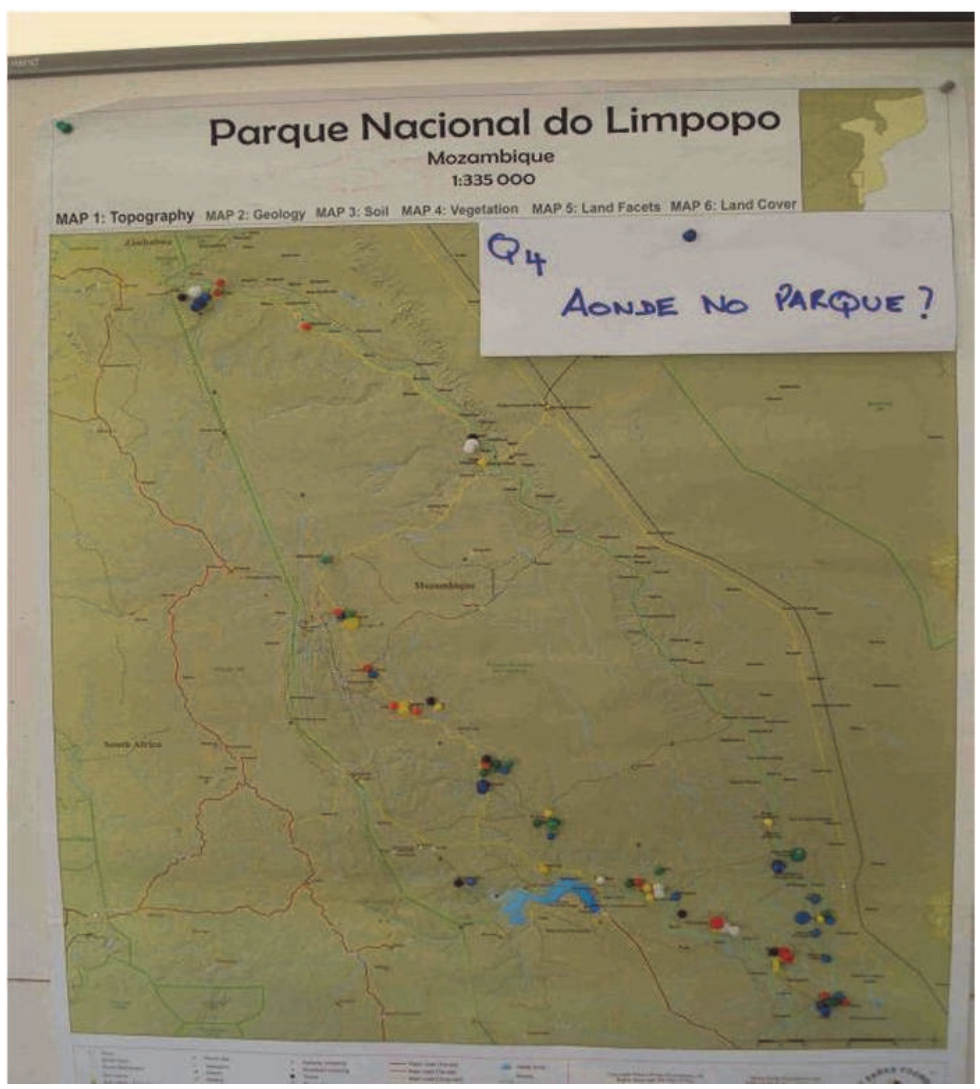

Fig. 11. South course HWC spots localization 


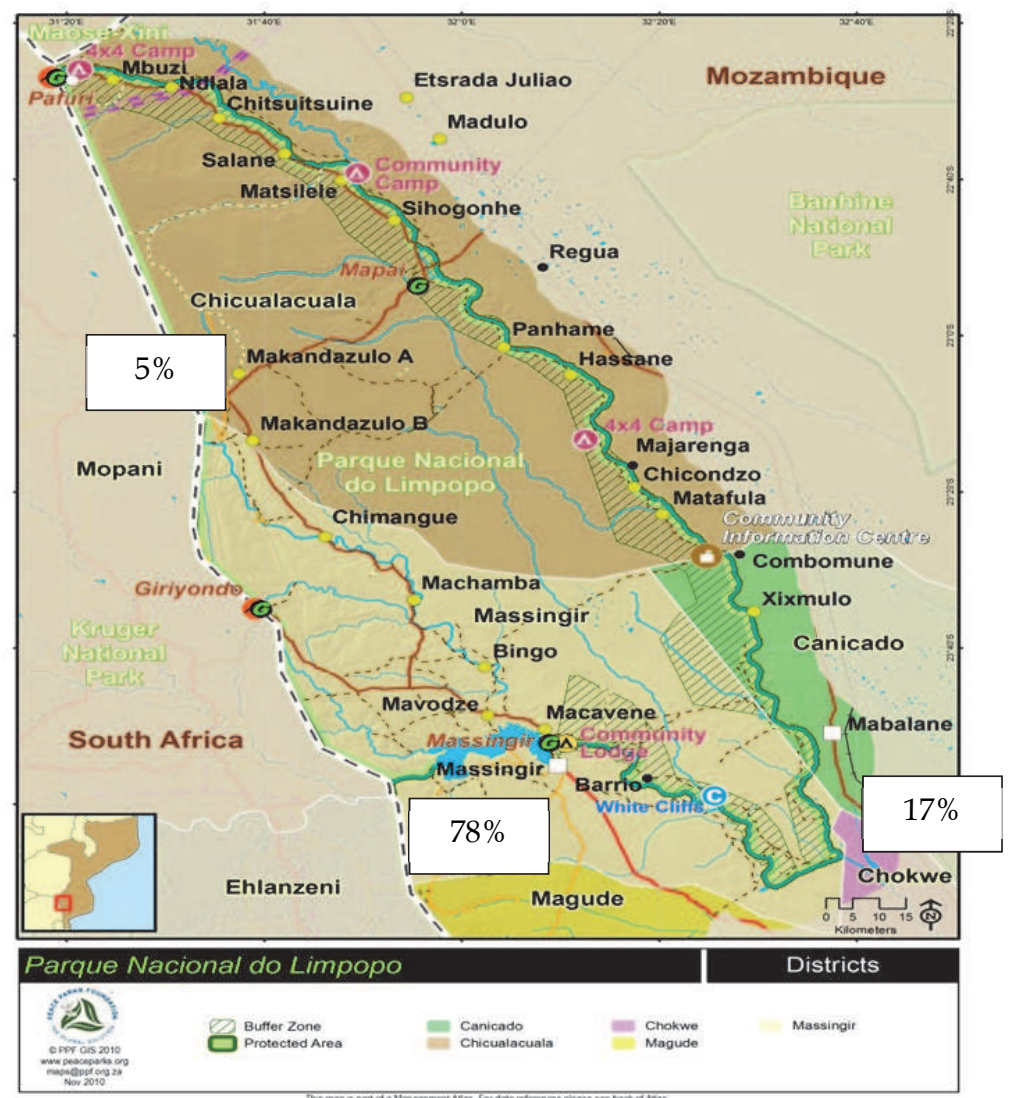

Fig. 12. Spatial records of HWC in LNP between 2007 and 2010

\subsubsection{Situations in which HWC occurs and categories of people in danger}

When asked "In which circumstances does HWC appear?" game rangers mentioned farming (31\%) and river based activities (27\%). Forests were mostly associated with the "lion risk" (71\%) and walking on a path had equal risk of encountering an elephant or a snake. Farming activity increased the risk of human-elephant conflicts (68\%) and the river represented a risky place for crocodile attacks $(82 \%)$ or problems with hippopotamus $(14 \%)$. The home is not necessary a safe place as it appears to be a site of conflict with snakes $(36 \%)$, lion $(24 \%)$ and hyena $(16 \%)$.

According to game rangers, the categories of people more likely to be involved in HWC are men $(40 \%)$ followed by women $(37 \%)$ and children $(24 \%)$. Children are most likely to be attacked by a crocodile (41\%), followed by a lion or an elephant $(18 \%)$. Men have conflicts predominantly with elephant $(54 \%)$ or lion $(30 \%)$ and women with crocodile $(56 \%)$ or elephant $(32 \%)$. These results, based on the perception of game rangers, are in line with 
human activities which could increase wildlife encounters. Nevertheless, information kept in the HWC data could not confirm this statement.

\subsubsection{Main impacts of HWC}

The impact of HWC is perceived by game rangers mainly as crops destroyed (49\%) followed by livestock being eaten $(27 \%)$ and people being killed or injured (24\%). Crops are mainly destroyed by elephant $(57 \%)$ and hippopotamus $(14 \%)$ and livestock are attacked by lion $(65 \%)$, crocodile $(22 \%)$ and hyena $(14 \%)$. People are mostly frightened and attacked by crocodile in the river $(42 \%)$, and lion $(27 \%)$ and elephant $(15 \%)$ in the field or in the forest.

The analysis of LNP data base revealed that human casualties are low at 3\% (12/384) and occurred mainly in Massingir (83\%). Crocodile were the biggest problem $(67 \%$ of human casualties), followed by hippopotamus at $17 \%$ and then buffalo and elephant (both $8 \%$ of human casualties). Most of the incidents recorded were related to crop destruction $(82 \%$, $316 / 384)$, mostly maize (48\% pure maize, $39 \%$ maize and vegetable, maize, vegetable and fruit trees $12 \%$ ), with an average of $75 \pm 6$ crop raids reported per year of which $93 \%$ were by elephant. During the same period, 723 fields were reported to be destroyed with an average of $2.3 \pm 0.3$ fields per incident $(n=384)$ but in $94 \%$ of the HWC no evaluation of destruction was conducted. The few assessments done $(n=18)$ gave an average of $0.11 \pm 0.03$ ha of crops destroyed.

Livestock predation represented a small volume of $\operatorname{HWC}(8 \%, 32 / 384)$ with the same proportion of cattle $(44 \%)$ or goats $(38 \%)$ preyed on in small numbers $(5 \pm 1, n=32)$. Lion were involved in cattle $(79 \%)$ and donkey $(100 \%)$ predation, and crocodile targeted sheep $(100 \%)$ or goats $(55 \%)$. The latter was also attacked by jackal $(18 \%)$ and baboon $(9 \%)$. In the last 4 years only one case of equipment destruction (irrigation pipe) by an elephant was recorded.

\subsubsection{Preventive measures taken by the communities}

Making noise and having ones property or field protected by a fence was perceived as the best way to prevent HWC (24\%). Other strategies mentioned were making fire $(20 \%)$, making noise $(17 \%)$ or fencing without making noise $(12 \%)$. The interesting point is the diversity of solutions reported by the game rangers, indicating (i) the importance of HWC and (ii) the motivation of local farmers to cope with such a problem (Fig. 13). The lack of detail information in the HWC database prevented any comparison.

For the elephant the main mitigation measures were to make fire $(32 \%)$, to beat drums $(30 \%)$ and combine fencing with making noise (19\%). Other techniques were used at lower frequencies. In order to minimize lion predation, farmers were firstly herding (40\%) and also making fire (20\%), preventing the access to the krall (corral) with strips (20\%) or stopping the lion with snares $(20 \%)$. Fencing $(33 \%)$, making noise $(33 \%)$ or combining both $(17 \%)$ with in some cases utilization of a flashlight $(17 \%)$ were the main techniques to repel buffalo. For the hippopotamus, farmers were mainly making fire $(36 \%)$ or combining fencing with beating drums $(36 \%)$, while the use of scarecrows was also reported. Fencing the water point and making noise $(40 \%)$ were the most successful deterrents for the crocodile, or simply to fence them out $(20 \%)$. The use of chili as a deterrent was also reported $(20 \%)$. Baboon were involved in crop raiding and in small livestock predation, methods reported by the game rangers varied from herding $(38 \%)$, using plastic strips to prevent access to crops $(33 \%)$ and also using dogs to alert $(13 \%)$. 


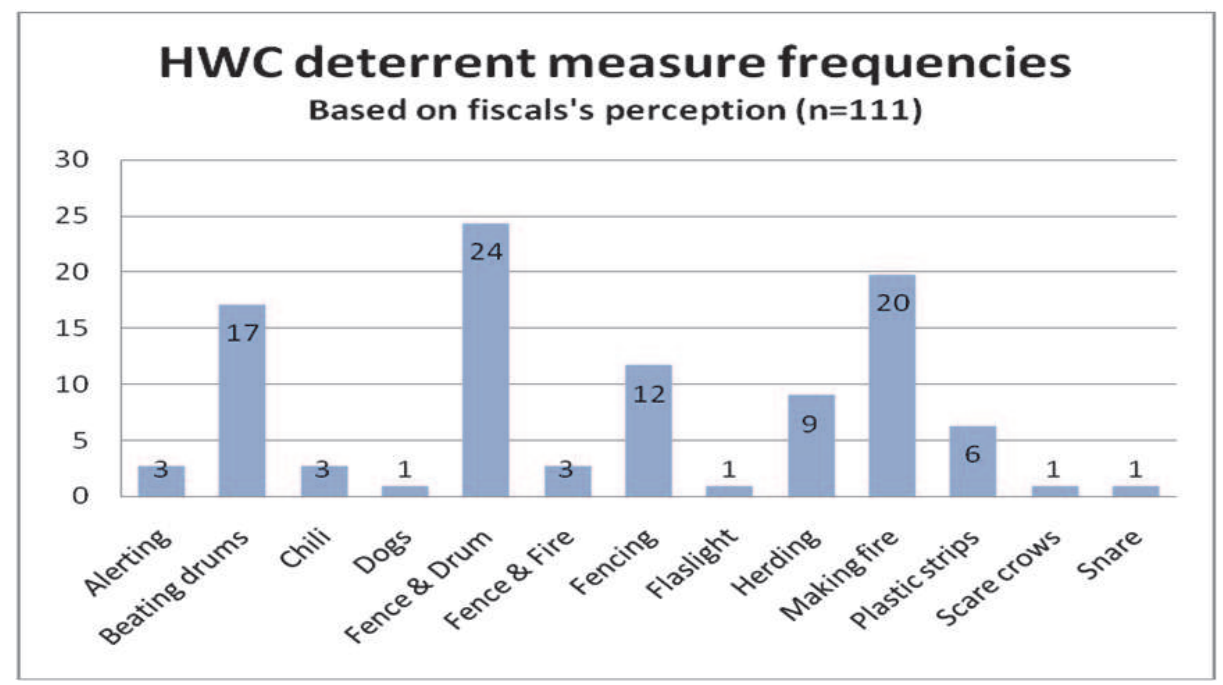

Fig. 13. Communities' mitigation measures

\subsubsection{Types of reaction taken by the fiscals}

The main game rangers intervention was to chase the animals involved in HWC (64\%) followed by killing them (19\%). Little was done to monitor or evaluate the situation $(9 \%)$ or provide awareness to farmers (8\%). Killing is used as a reprisal to all species $(57 \%)$ but especially to crocodile (14\%), buffalo $(14 \%)$, elephant $(7 \%)$ and lion $(7 \%)$. This attitude was partly confirmed by the HWC data base with $53 \%$ of game rangers reporting chasing problem animals and 36\% evaluating the situation. Killing seems to be rarer than was perceived with an average of one animal killed per year $(1.3 \pm 0.2,1$ to $4, n=21)$ between 2007 and 2010, mainly elephant (50\%), crocodile (25\%) and lion (25\%).

\section{Understanding Human Wildlife Conflict (HWC) in areas adjacent to national parks and conservancies in Mbire, Chiredzi and Hwange districts, Zimbabwe}

\subsection{Background}

Zimbabwe is endowed with a stock of natural resources that could support the development of a diversified economy, thus enabling the country to address social development issues. To reach its objectives of food security and sustainable environment preservation, the country faces important challenges, the most important being the existence of acute conflicts between rural communities and wildlife. Recently conflicts between human and wildlife became one of the biggest obstacles for community-based natural resource management in Zimbabwe, this situation been exacerbated by the 1999 Land Reform which resulted in Africans settling on former white owned commercial farms, as well as game safari land and sections of National Parks.

When examining causes, several interlinked factors could be identified. The post colonialism period was marked by profound changes in landscape arrangement. Firstly restructuring of the agricultural sector and general human population growth had resulted in human encroachment on wildlife habitat and natural movement corridors. 
Changes in individual land use strategies involving the switch from large fields to scattered cultivated lands likely contributed to increased conflicts in rural lands adjacent to Protected Areas. Meanwhile, because of the high rate of unemployment and increasing poverty, the area of subsidence farming of cultivated lands expanded. Growing poverty has led to the over-exploitation of natural resources and the increase of illegal activities including poaching. Inevitably an augmentation in conflicts between poor communities living side-by-side with Protected Areas and wildlife has been experienced. In addition, the situation is exacerbated by insufficient revenue from wildlife to communities resulting in their decreased tolerance level towards wildlife. The direct costs to local communities encompass threat to human life and economic losses with a decrease in agriculture performances. HWC are also extremely costly in term of wildlife conservation. Revenge killing of problem animals leads to the death of non-targeted animals. The use of snares, traps, poisoned water and poisoned carcasses may affect the entire biodiversity chain. Conflicts can represent a real threat to endangered and protected species. Local revenue generated through hunting tourism can also be reduced when there is excessive removal of trophy animals under problem animal control (PAC) activities. Ultimately, people tend to develop a negative attitude towards wildlife management and conservation initiatives proposed by the government or conservation authorities. This in turn can lead to noncooperation of local communities and increased instances of poaching and other illegal activities.

The main objectives of this baseline survey were to: determine the drivers of HWC, characterize the spatial and temporal dynamics of $\mathrm{HWC}$, and explore the relationships between the frequency of HWC and environmental factors at community level.

\subsection{Materials and methods}

\subsubsection{Study sites}

The study was conducted in three sites located in Hwange, Mbire and Chiredzi districts of Zimbabwe (Fig. 14). Each study site was adjacent to conservation areas. In Hwange district, the study site comprised wards 11, 14, 15, 16 and 17. In Mbire district, the study was conducted in wards 1, 2, 3, 9 and 12, while in Chiredzi district, the study site comprised wards $1,22,24,26$ and 32 .

\subsubsection{Sampling and data collection}

To determine the levels of human-wildlife conflict in each study site, we administered questionnaires to randomly selected households to solicit information on the type and frequency of occurrence of HWCs. In each study site, households were selected following several steps. Firstly, we digitized and mapped all homesteads in the selected wards based on 2010 SPOT satellite image in Google Earth (http/google.earth.com). The satellite image had a spatial resolution of $2.5 \mathrm{~m}$ which made it possible to detect homesteads. Secondly, in Chiredzi district, we randomly selected homesteads within each sampled ward from a population of homesteads mapped using the method described above. In Hwange and Mbire districts, we generated and overlaid at least four transects in a Geographic Information System (GIS). Transects originated at conservation boundaries and passed through human settlements (homesteads) and were oriented in such a way that some homesteads were closer to the boundaries of protected areas (mostly National Parks) while others were farther away. Along each transect, homesteads were selected at random. This 
sampling strategy was employed to gather data for testing whether the frequency of occurrence of HWC is related to distance from conservation areas.

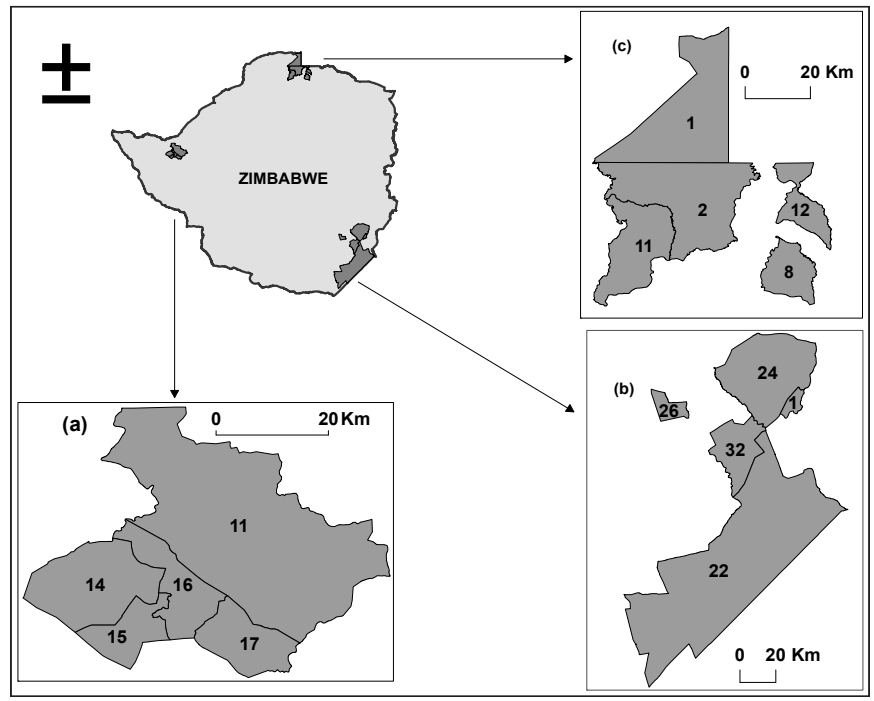

Fig. 14. Location of (a) Hwange, (b) Chiredzi and (c) Mbire study sites in Zimbabwe

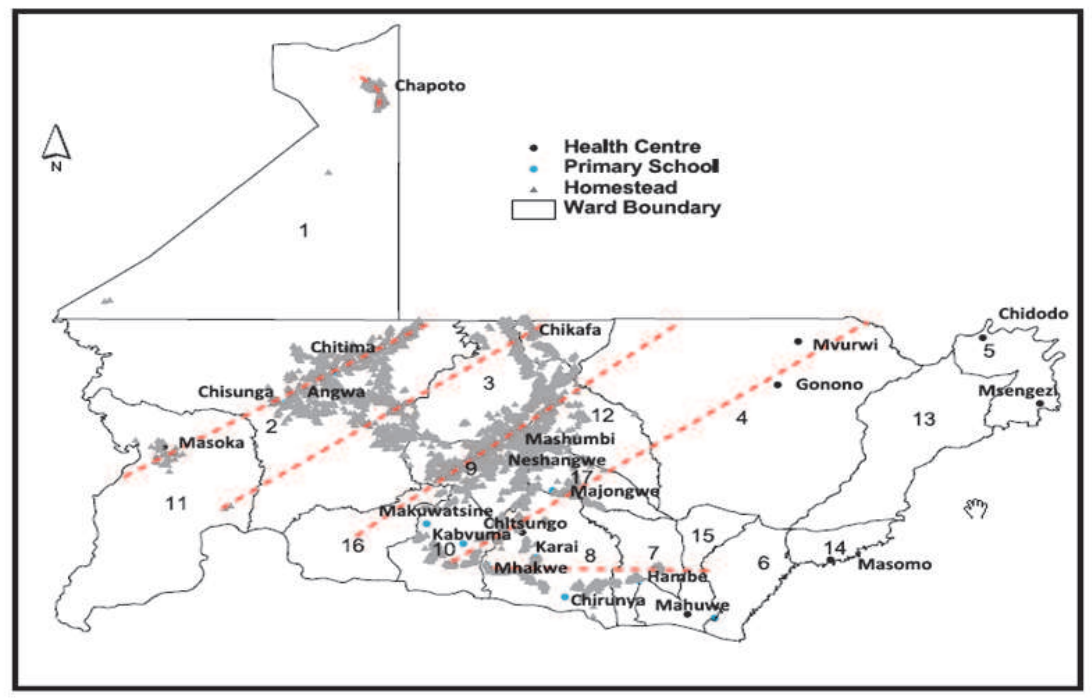

Fig. 15. The distribution of sampled homesteads along transects in Mbire district, Zimbabwe

The coordinates of the selected homesteads were stored in a Global Positioning System (GPS) unit, which was used to locate the homesteads in the field. Data on the location of sampled homesteads was used to aid analysis of the spatial patterns of HWC in each study 
site. Figure 15 shows the distribution of the homesteads in selected wards along transects in Mbire districts. At each of the selected homesteads, the most senior household member belonging to that homestead was interviewed.

\subsubsection{Data management and analysis}

Data collected during the questionnaire surveys were captured and managed in a database that we specifically designed for analyzing HWC in Microsoft Access (MS Access). The main goal for designing and developing a database for HWC was to enable an understanding of the changing nature of HWC in space and time; in order to achieve this the database was equipped with a simple data entry interface which enables capture of data on HWC in the future.

To facilitate statistical analysis of the HWC across the three study sites, questionnaire data were also captured in a statistical package (Statistical Package for the Social Sciences, SPSS). SPSS was also used to explore and understand the relationships between the spatial patterns of HWC, their seasonal dynamics and several household characteristics that include sources of livelihoods, time of settlement, ethnicity and perception of HWC, as well as ecosystem services in the study sites. The main objectives of these analyses were to determine and explain the geographic distribution of HWC in relation to key household characteristics such as time of settlement and location of settlement, and to ascertain whether the level ecosystem services in a site was a key driver of the spatial variations in the perceptions and occurrence of HWC. To map the geographic distribution of HWC and isolate hotspots of conflict, we first mapped and plotted as point data all households who either reported or did not report that they had experienced any HWC such as crop raids by wildlife. We then plotted the intensity of HWC by fitting a kernel function on point data indicating the locations of households that reported conflict in a GIS. This analysis was only performed for study sites in Hwange district because the data was suitable for this type of spatial point pattern analysis. The plotted function enabled us to visually explore patterns in HWC.

For Mbire and Chiredzi districts we used logistic regression to relate the occurrence/nonoccurrence of HWC with environmental factors such as the distance from the conservation area boundary and vegetation cover. Vegetation cover was estimated remotely from Landsat Thematic Mapper (TM) satellite image of May 2010 using the normalized difference vegetation index (NDVI). The purpose of this analysis was to test whether the observed spatial pattern in HWC was significantly related to environmental factors. $\mathrm{P}<$ 0.05 was used as the critical level of significance. Where logistic regression functions relating environmental factors to HWC were significant, the functions were in turn used to map the spatial distribution of the probability of occurrence of HWC in each of the three study sites in a GIS. All statistical analyses were performed using SPLUS version 8 (Insightful Inc.) while Arc View GIS and ILWIS GIS were used for spatial analysis and mapping.

\subsection{Results}

\subsubsection{Spatial aspects of HWC in the study sites}

Figure 16 shows that in Hwange and Chiredzi districts, a significantly higher proportion of households reported that they experienced an HWC incident but in Mbire, the difference between households that reported HWC and those who did not is small. 


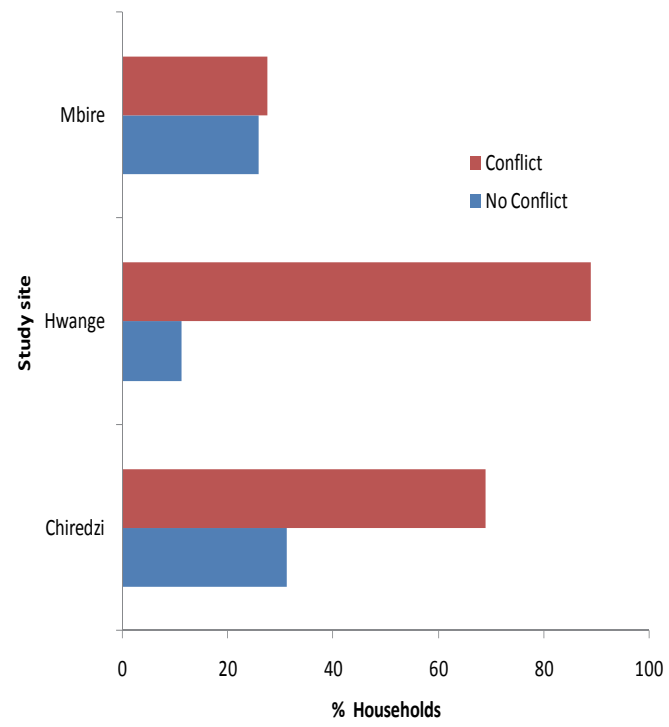

Fig. 16. Occurrence of HWC in the study sites $(n=613)$

Figures 17 and 18 show the spatial distribution HWC in Hwange and Mbire study sites, respectively. In Hwange, HWC were mainly concentrated in wards 15, 16, and 17 which are adjacent to Hwange National Park. In Chiredzi, HWC were also concentrated inside and closer to Gonarezhou National Park. In Mbire, the situation is different. There are no observable clusters of HWC.

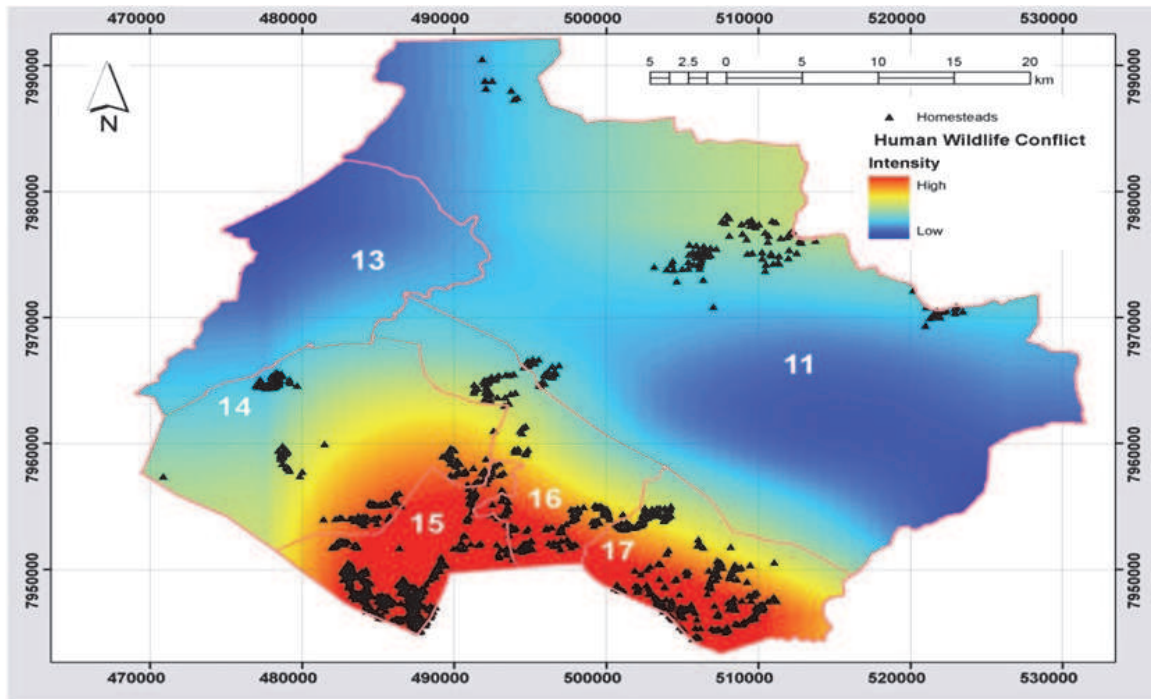

Fig. 17. The distribution of the intensity of HWC in the study wards in the Hwange study site based on fitting a kernel function on the occurrences of HWC 
Human Wildlife Conflicts in Southern Africa:

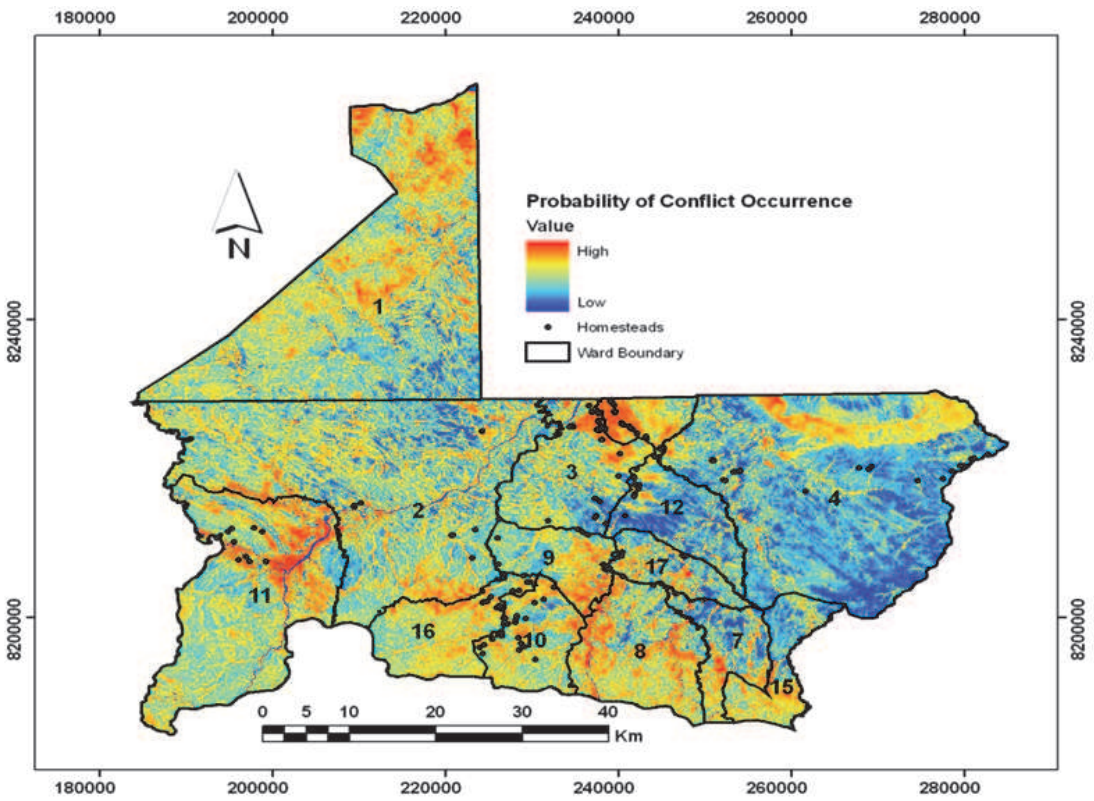

Fig. 18. The distribution of the intensity of HWC in the study wards in the Mbire study site

\subsubsection{Biophysical characteristics in the HWC sites neighbourhood}

The probability of occurrence of HWC in the study sites was significantly related to vegetation density (Fig. 19). This indicates that areas that have high vegetation cover are

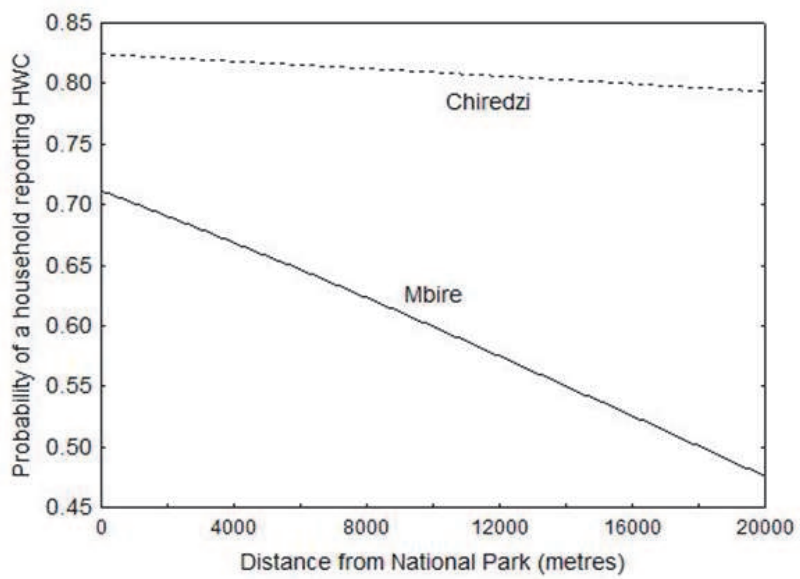

Fig. 19. The probability of HWC in Mbire and Chiredzi correlated to distance from conservation areas

associated with high incidents of HWC. Figure 20 illustrates that there is a significant negative relationship between increasing distance from the National Parks and the 
probability of occurrence of HWC, specifically for Mbire and Chiredzi study sites. For the Hwange study site, there is also a negative relationship between the probability of HWC occurrence and distance from Hwange National Park but this holds only when the vegetation density is high (Fig. 21). This suggests that areas that are closer to Hwange National Park but have low vegetation density are less likely to experience elevated levels of HWC than those which are closer and more densely vegetated.

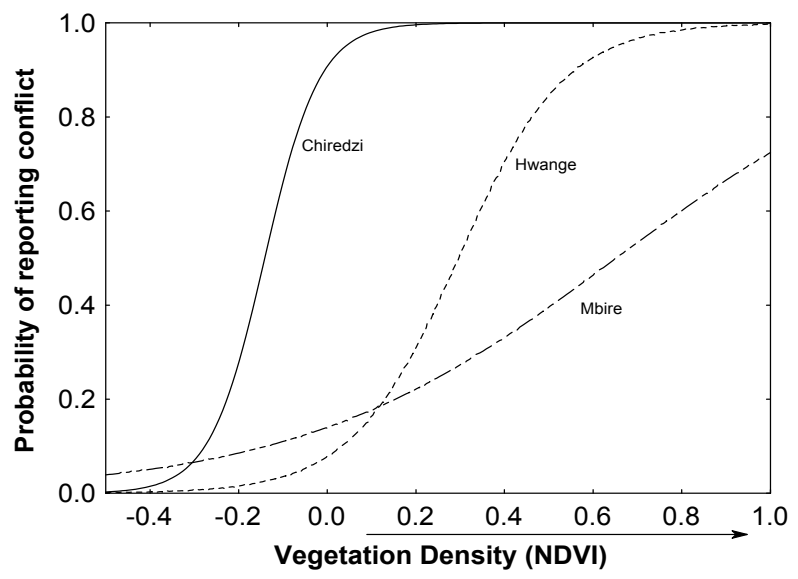

Fig. 20. The probability of HWC in Hwange, Mbire and Chiredzi in the study sites as a significant $(\mathrm{P}<0.05)$ function of NDVI (vegetation density)

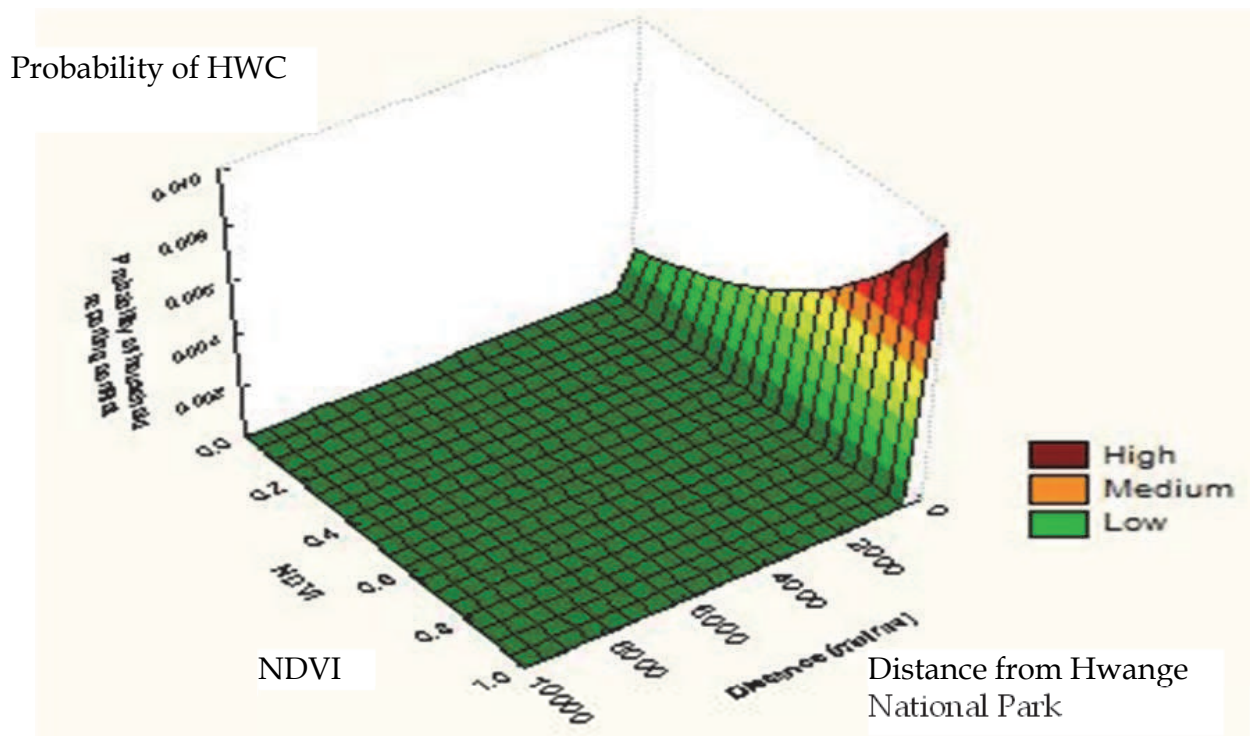

Fig. 21. The probability of HWC in Hwange as a function of the interaction of distance away from Hwange National Park boundary and vegetation density (NDVI) 
Moreover, results from specific sites where HWC incidents take place reveal that most HWC incidents occur in the fields $(85 \%, \mathrm{n}=387)$. Observed differences are highly significant (Pearson Chi-Square $=49, \mathrm{df}=8, \mathrm{p}=0.001, \mathrm{n}=387$ ) with $93 \%$ of HWC occuring in the field in Chiredzi, $85 \%$ in Hwange and $78 \%$ in Mbire.

\subsubsection{Temporal aspects of HWC in the study sites}

\subsubsection{Diurnal dynamics of HWC}

The survey investigated temporal aspects of HWC in all three study sites these included seasonal as well as diurnal distribution of raids or attacks. In all the three study sites, most of the attacks or raids occurred during the night with $86 \%$ of HWC. Chiredzi district had the highest number nocturnal attacks (94\%), followed by Hwange (84\%) and Mbire (82\%). Mbire accounted for the highest number of attacks happening during the afternoons $(12 \%)$ followed by Hwange $(8 \%)$ and Chiredzi $(2 \%)$. Observed differences are significant (Pearson Chi-Square $=10, \mathrm{df}=4, \mathrm{p}=0.034, \mathrm{n}=410)$.

\subsubsection{Seasonal dynamics of HWC}

The survey investigated respondents' experiences regarding the seasonal movements of wild animals into human settlements and arable fields. Results show that in all the three study sites most HWC occurred in summer with $89 \%$ of incidents observed. Differences between the three districts are highly significant (Pearson Chi-Square $=23, \mathrm{df}=4, \mathrm{p}<.000$, $\mathrm{n}=426$ ) with Hwange having the greatest number of HWC during the summer $(94 \%)$ and Mbire a significant number of raids during winter (17\%).

\subsubsection{Movements of wild animals into human settlements and arable lands in the winter season}

Elephants are the main problem animals, involved in half of HWC incidents (predominating in summer vs. $27 \%$ in winter) with a high prevalence in Chiredzi (78\% of incidents reported). Hyenas are perceived as the second most problematic animal by the farmers, involved in $17 \%$ of HWC in summer and $28 \%$ in winter. Baboons and wild pigs are mentioned as a problem in summer ( $\%$ of HWC), lions and buffalos are more active in winter with respectively $17 \%$ and $11 \%$ of HWC incidents reported by the informants. Differences between the three districts are highly significant (Pearson Chi-Square=111, $\mathrm{df}=18, \mathrm{p}<.000, \mathrm{n}=358$ ) and can be summarized as followed in descending order:

- Mbire District:

- In winter: Elephant $(24 \%)>$ buffalo $(18 \%)>$ hyena $(18 \%)>$ baboon $(16 \%)>$ lion $(15 \%)$.

- In summer: Elephant $(47 \%)>$ wild pig $(17 \%)>$ baboon $(12 \%)>$ buffalo $(8 \%)>$ hippopotamus $(7 \%)$.

- Chiredzi District:

- In winter: Elephant $(34 \%)>$ lion $(29 \%)>$ hyena $(22 \%)$.

- In summer: Elephant (78\%).

- Hwange:

- In winter: Hyena $(51 \%)>$ elephant $(26 \%)>$ lion $(12 \%)$.

- In summer: Elephant $(50 \%)>$ hyena $(32 \%)>$ baboon $(8 \%)$ 


\subsubsection{Socio-economic characteristics and HWC including cropping and grazing practices}

We also assessed the probability of reporting HWC as a function of the time a homestead was established. It is clear that recent settlers are more likely to report incidents of HWC than early settlers. This finding implies that recent settlers are allocated land closer to park boundaries and therefore buffer the older settlements from HWC. Logistic regression confirmed that the negative relationship between the probability of a household (respondent) reporting conflict and the time the household's homestead was established was significant $(\mathrm{p}<0.05)$. A further investigation on HWC reporting patterns by households shows that the level of education has an influence on HWC (Fig. 22). Respondents with only primary education constituted the highest number of those who reported HWC.

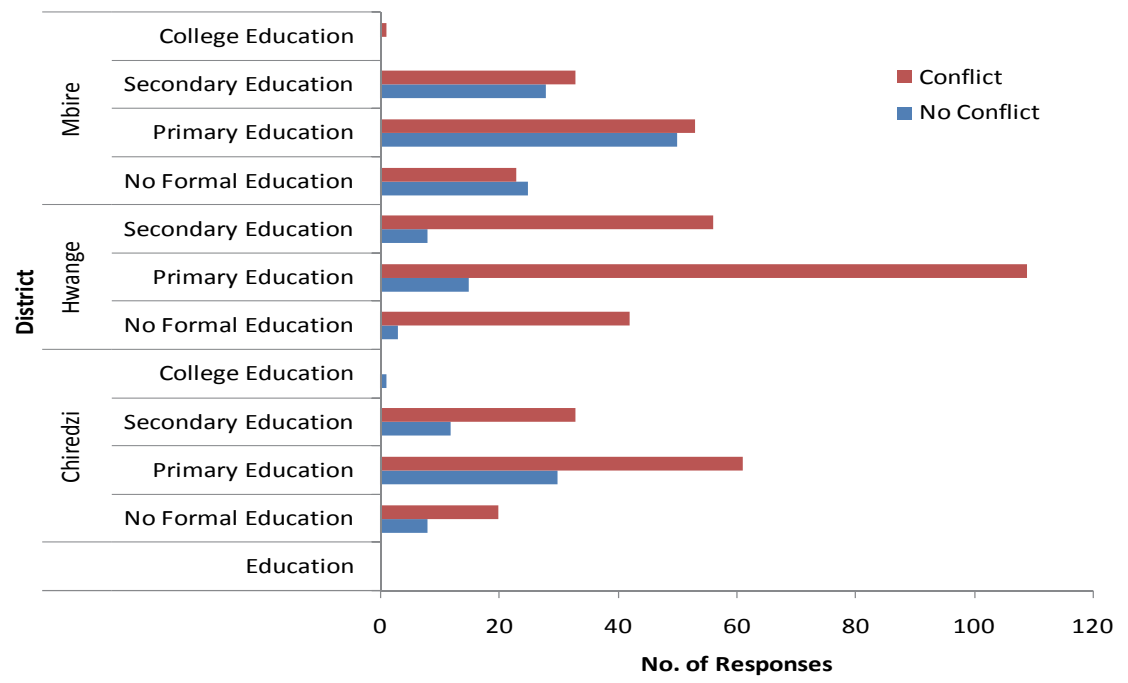

Fig. 22. Number of households (respondents) who reported the occurrence and nonoccurrence of HWC in the three different study sites $(n=613)$

\subsubsection{Consequences and responses to HWC by households}

\subsubsection{Effect of wild animals on crops, animals and persons}

The major impact of HWC is crop destruction (77\% of HWC reported by informants) followed by animal predation $(17 \%)$ and human casualties $(6 \%)$. The differences observed between the three districts are highly significant (Pearson Chi-Square $=78, \mathrm{df}=4, \mathrm{p}<.000$, $\mathrm{n}=407)$ with Chiredzi mostly affected by crop raiding (94\%), Hwange having the highest percentage of livestock attacked $(25 \%)$ and Mbire having the greatest number of persons being attacked by wildlife $(20 \%)$.

The most vulnerable crops to raiding by wild animals include maize $(43 \%)$, cotton $(35 \%)$ and sorghum (16\%) but significant variations exist in terms of crops raided by wild animals across the study sites (Pearson Chi-Square=232, df=18, $\mathrm{p}<.000, \mathrm{n}=537$ ). Maize which is a staple food in all three study sites is the most raided crop, especially in Hwange (56\%) and in Chiredzi (50\%). Second on the list of crops mostly raided by wild animals is sorghum, which is a traditional staple crop mainly in Hwange $(28 \%)$. Results also show that cotton 
raids are largely specific to Mbire (67\%) and Chiredzi (31\%), and less common in Hwange (2\%). In Mbire, cotton started being introduced after the eradication of tsetse fly in the mid 1980s and is fast expanding. With the support of local and multinational companies, such as Cottco, and Cargill and Olam, cotton has also been introduced in Chiredzi by newly resettled farmers.

\subsubsection{Responses to wild animal attacks/raids by local people}

Human wildlife conflict calls for action at different levels. In all the three study sites households report wild animal attacks to traditional leaders (33\%), Problem Animal Control (PAC) unit $(16 \%)$, or a councillor $(13 \%)$ but one third of informants are not making reports. However the reporting system even in the same site differs (Pearson Chi-Square $=54, \mathrm{df}=14$, $\mathrm{p}<.000, \mathrm{n}=443$ ). In Mbire, households are mainly reporting to traditional leaders (41\%) or to the Problem Animal Control unit (24\%). In Chiredzi complainants report either to traditional leaders $(36 \%)$ or chose not to report (39\%). In Hwange, most respondents $(40 \%)$ indicated that they do not report problem animals to anyone.

In addition to reporting problem animals, affected households also undertake activities to lessen the impact of wild animal attacks. Most households tried to chase or scare the animal away $(70 \%)$ and a significant proportion did not react (18\%). Mitigation measures differ significantly between the three sites (Pearson Chi-Square $=69, \mathrm{df}=6, \mathrm{p}<.000, \mathrm{n}=492$ ). Apart from trying to chase the animals away, in Mbire, a certain proportion of households call National Park's personnel (16\%) or even to kill problem animals $(7 \%)$ while in the two other districts a significant proportion (20\% in Hwange and 30\% in Chiredzi) are doing nothing.

The study investigated satisfaction levels of respondents in relation to responses by responsible authorities to problem animals across the three study sites. All three districts reflected negativity with the least satisfied respondents being in Hwange (97\%), Chiredzi $(92 \%)$ and Mbire $(82 \%)$. The interesting finding here is that respondents living close to a National Park are the least satisfied, followed by those living close to a local authority controlled Safari Hunting areas. In terms of this survey, though not very statistically significant, respondents living close to a privately controlled Conservancy are more satisfied than their counterparts.

\subsubsection{Assessment of compliance with regulations and perceptions on natural resources}

\subsubsection{Community resource assessment and HWC}

Results show that several factors contribute to the HWC in the study sites. Most respondents in the study sites attribute the occurrence of HWC to the decline of the natural resource base. Climate change and human activities such as the opening of new fields and homesteads are also viewed as important drivers of the decline in the status of the natural resource base. Observed differences between the 3 sites are highly significant (Pearson ChiSquare $=37, \mathrm{df}=4, \mathrm{p}<.000, \mathrm{n}=544)$.

\subsubsection{Compliance to wildlife regulations}

Rules are in place to regulate the human benefits derived from the environment. However, the benefits can only accrue if people know and comply with the rules set. Compliance depends on whether the affected individuals perceive such rules as beneficial. Two third of households felt that when rules are observed, the community is likely to benefit; they are 
$70 \%$ in Hwange compared with 50\% and 67\% in Mbire and Chiredzi, respectively. Observed differences are highly significant (Pearson Chi-Square=19, df=2, $\mathrm{p}<.000, \mathrm{n}=519$ ).

\subsubsection{Perceptions on wildlife}

Overall, most respondents perceive wildlife as a threat to both people and domestic animals but perceptions differ as to whether disease transmission, destruction of crops and human and livestock predation are the key threats within and across study sites. Chiredzi has the highest percentage of respondents who perceive wildlife to be a threat to both humans and livestock (94\%), followed by Mbire $(87 \%)$ and Hwange (85\%). Transmission of diseases is perceived to be a major threat by $73 \%, 20 \%$ and $7 \%$ of the respondents in Mbire, Chiredzi and Hwange study sites, respectively. Destruction of crops by wildlife is also a threat in all study sites identified by $37 \%, 34 \%$ and $28 \%$ of the respondents in Chiredzi, Mbire and Hwange study sites, respectively. Similarly, predation on humans and domestic animals is also considered as a threat in all three study sites by 35\% of respondents in Chiredzi, $33 \%$ in Hwange and $32 \%$ in Mbire.

\section{HWC, living with uncertainty in Southern Africa}

\subsection{An on-going problem with various expressions}

Human population growth, agricultural expansion into wildlife areas, and habitat loss contribute to increasing HWC. In Mozambique, the prevalence of HWC has been multiplied by 4.3 between 2006 and 2010. In Zimbabwe, between 2002 and 2006, more than five thousand cases of Human-Elephant Conflicts (HEC) were recorded of which around three thousand cases were attended to, resulting in 774 elephants being killed during subsequent problem-animal-control operations (Campfire Programme, 2007). The survey conducted in 2010 in the three districts echoes to this finding with a significantly higher proportion of respondents reporting the occurrence of HWC.

Nevertheless, observations suggest that records of HWC are largely underestimating the occurrence of the problem. The lack of information is linked either to the fact that, like in Hwange District in Zimbabwe, a significant proportion of respondents (40\%) feel helpless to report problem animals to anyone, or from the absence of a good recording system. As an example in Mozambique, DNTF recorded 200 HWC between 2006 and 2010 in Gaza Province while the staff of the Limpopo National Park in the same province reported the doubling of incidents for a shorter period (2007 - 2010).

The study of the temporal pattern acknowledged the reality that HWC is occurring all year long even if in some places significant differences are perceived or recorded by Wildlife Authorities. It is difficult to identify specific seasons or months more at risk as it depends on social and ecological factors (see above) but it is evident that most attacks or raids occurred during the night with the exception of crocodile accidents which are linked to specific sites (rivers) and water based activities. According to Samu (2010) in Hwange and Mbire districts, night attacks occurred while people are busy guarding their crops; Cumming et al. (1982) linked gender to human attacks by wild animals and observed that most people who are attacked and killed by wild animals are males mainly because they herd cattle, forage for bush meat and walk alone during the night. A study by Kock (2003) corroborates the above by mentioning that activities around the settlements such as the collection of wild fruits, fishing and poaching increased the inhabitants risks of wildlife attacks. 
Cumming et al. (2007) pointed out that human deaths and injuries are less common than crop damages. The low occurrence of human casualties observed in Zimbabwe, or in the buffer zone of the Limpopo National Park with 3\% of HWC, must not hide the fact that it can be much more significant at local (Mbire District) or country level (Mozambique) with, for the latter, up to $25 \%$ of HWC reporting human casualties mainly by crocodile $(61 \%)$.

This impact is of serious political concern (Lamarque, 2010); however, HWC expression is more likely to include crop or livestock losses, asset destruction and the less mentioned spread and dissemination of wildlife borne pathogens (WWF, 2005). In the two countries, crop destruction is a greater issue than livestock destruction, although the latter can be a specific problem (e.g. hyenas) in certain areas (Hwange buffer zone). Elephant appear to be the main species ( $80 \%$ of cases) involved in crop raiding with destruction in some areas reported to be more than half the anticipated yield. In addition to this direct cost of HEC, indirect impacts include restrictions on movement of people, access to key resources, such as water, firewood and thatching grass as well as the transaction costs, of guarding crops and property against wildlife degradation, resulting in negative attitudes towards wildlife and increases in unsustainable and unregulated hunting (WWF-SARPO, 2005). A number of studies on crop and livestock predation reported have a negative impact on the local economy (Katerere, 1997; Barnes, 1998; Murphree, 2005; FAO, 2009). This last point is reflected by informants both in Mozambique and in Zimbabwe but is not supported by a good evaluation system; most of them, like the case of LNP $94 \%$ of crop destruction, have not been assessed.

\subsection{Fuelled by the increase of human and wildlife population 4.2.1 From crops raiding elephants...}

With elephant populations in southern Africa increasing at 5\% per annum (Blanc et al., 2005; Cumming \& Jones, 2005) together with the expansion of human settlement into wildlife areas, local communities living in marginal land adjacent to protected areas are faced with increasing occurrences of HEC (Nelson et al. 2003). The aetiology of HEC differs depending on the area but is linked by space requirements for human development which clashes with the ecological needs of elephants. In that sense, it is predictable that human growth (Fig. 25) will progressively increase the number and intensity of HEC in Africa as about $80 \%$ of elephants range lies outside protected areas. The potential range expansion in southern Africa may be able to accommodate up to about 75,000 elephants (Fig. 26), the equivalent of $15 \%$ of the regional population of elephants (500,000 elephants) in the next 12 to 15 years (Cumming \& Jones, 2005).

\subsubsection{To crocodile crimes}

With a third of HWC recorded mainly in the Zambezia and Tete provinces, crocodiles are the second main problem animal in Mozambique responsible for two thirds of human casualties. The main reason is the lack of natural food due to over-fishing, and risky behaviour (Anderson \& Pariela, 2005). In addition, conservationists are implementing the successful re-introduction of crocodile in big head waters such as Lake Kariba in Zimbabwe (McGregor, 2005). Considering the nature of the accident, the numbers of casualties are likely to be under-reported (Anderson \& Pariela, 2005). 


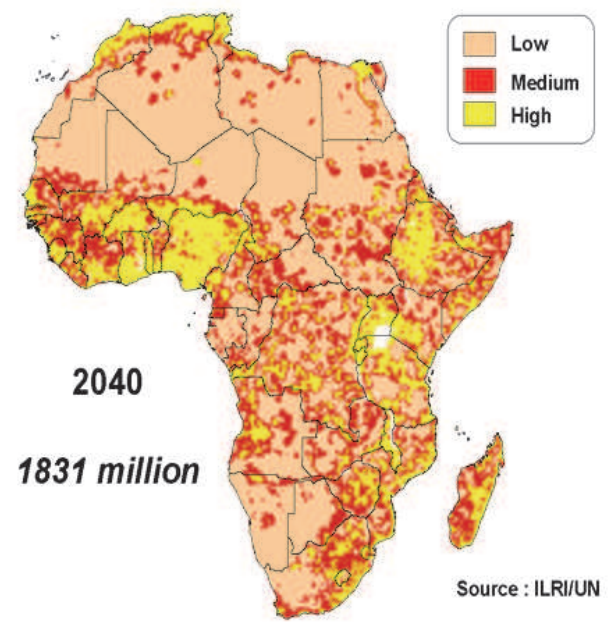

Fig. 23. Human growth in Africa

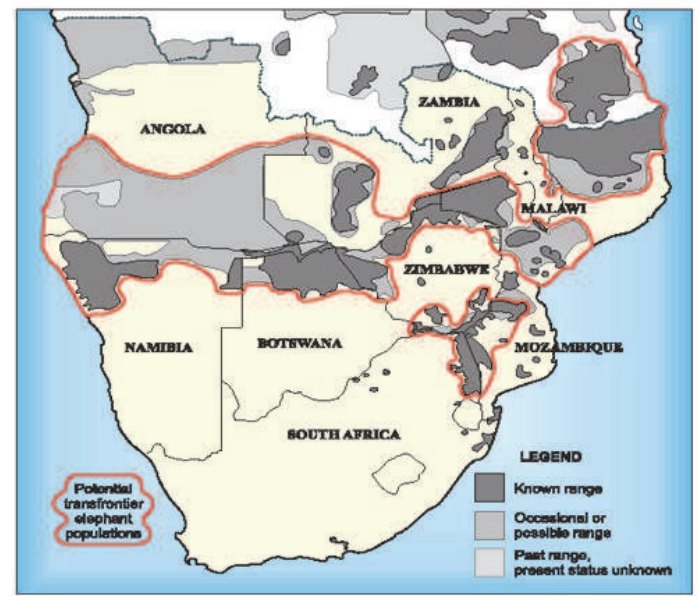

Fig. 24. Potential expansion range for elephant populations in Southern Africa

\subsection{Spatial distribution and HWC dynamics}

According to Steinfeld et al. (2006) competition for space and available resources between people and wildlife is the major driver of HWC. It is also generally assumed that HWC used to be low when resources (land, food and water) were in abundance for both people and wildlife. The competition reduced the 'once' peaceful co-existence of people and wildlife. In the particular case of these districts in Zimbabwe, the spatial distribution of the reported human wildlife conflict incidents show evidence of clustering especially in areas closer to conservation areas. We therefore conclude that human wildlife conflict incidents are not randomly distributed but form clusters (hotspots) in relation to distance from conservation areas, as well as, vegetation density. In Mozambique, the roots of HWC have been analysed 
by the National Strategy for HWC mitigation (FAO, 2009). The lack of land use plan which leads to anarchic human settlements in wildlife areas and to the destruction of the natural habitat is a major explanation for HWC between people and elephant (Araman, 2009). As mentioned above, the poor access to water supplies is another common cause of HWC, notably with crocodile (Ministério da Agricultura 2009).

This finding echoes events within the buffer zone of the Limpopo National Park where 10 villages out of 44 are experiencing most of the conflicts with wildlife. It also opens another dimension when wildlife conservation policies are extending land targeted for wildlife into grazing and arable land which is highly valued by pastoralists and agriculturalists (Kock, 2003). With the Coutada 16 proclaimed as the Limpopo National Park in November 2001, all the ingredients for the emergence of a typical HWC hotspot were combined: (i) an important human population $(25,000)$ living along the Elephant and Limpopo rivers; (ii) a scattered, but increasing wildlife resource (Blanc et al., 2007), due to the translocation of animals and the lowering of fences between Kruger and Limpopo National Parks; and (iii) a water surface system dictating the distribution of wildlife during the dry season (Magane et al., 2003). With elephant occurring at low densities, Limpopo National Park is already facing crop damage (BRL, 2006) with an average of 32 incidents per month. It is not only a finding from the analysis of the HWC data base which indentified Gaza and Cabo Delgado provinces as elephant conflicts hotspots, but the perception of LNP game scouts who scored elephant as their main problem animals. The problem is getting worse if we consider that a systematic survey conducted in 2006 (Whyte, 2006) gives an estimation of 0.06 elephant per $\mathrm{km}^{2}$ which is less than the density observed in the two neighbouring parks ( 1 elephant per $\mathrm{km}^{2}$ in Gonarezhou; 0.63 elephant per $\mathrm{km}^{2}$ in Kruger) (Blanc et al. 2007). With the free movement from Kruger and natural population growth which may mean a population doubling in less than 15 years, there may soon be up to 2,000 elephants living in the Buffer Zone of LNP, undermining the development of LNP and compromising the support to the Great Limpopo Transfrontier Conservation Area.

Competition for water resources especially during the dry season is a classic source of HWC (Butler, 2000) when permanent settlements are depriving wildlife access to water. Murphree (2005) and Steinfied et. al. (2000) cite conflict over access to water bodies as a major source of HWC, especially with crocodiles attacking both humans and livestock (Anderson \& Pariela, 2005; McGregor, 2005).

The reporting patterns of respondents in Zimbabwe shows that recent settlers (1980s-2000s) have more problems with wildlife attacks compared with their earlier settlers. Coupled with evidence that attacks were occurring closer to conservation areas and that these attacks were mainly on crop fields, we can conclude: that (1) crop based land use practices of recent settlers attract wildlife attack and (2) that these settlers are located in densely vegetated areas close to the wildlife frontier, which mainly explains the high incidents of human wildlife conflict involving recent settlers. Human migration is a major driver of HWC (McGregor, 2004). Harsh living conditions characterised by droughts, floods, civil unrest and sometimes wars disrupt the livelihoods of rural people and force them to move to wildlife areas such as National Parks, where resources like fuelwood tend to be more readily available (Hulme \& Murphre, 2001). It is important to note that in many parts of Africa, protracted civil wars and civil unrest force people to seek shelter in Protected Areas where they exert pressure on the natural resources and compete with wildlife resulting in increased cases of HWC (Mizutani et al., 2005; Steinfeld et al., 2006). As discussed above, immigrants are less likely to protect wildlife which they view as a competitor. 


\subsection{Competing attitudes and perceptions}

The majority of the respondents perceive wildlife as a threat and, in addition, natural resources as dwindling. However, most respondents also agree that if rules are observed, wildlife will be beneficial to communities. Thus, we conclude that there is room for sustainable management of natural resources including wildlife among the communities that live close to protected areas, but this still has a long way to go. In the meantime, HWC results in negative impacts on human social, economic or cultural life, on the conservation of wildlife populations, and on the environment, and play a major role in the perception of local communities neighbouring protected areas and ultimately, in the success of conservation strategies. Murombedzi (1999) reported that people living with wildlife and who encounter problems on a daily basis often display negative attitudes towards wildlife. They often perceive wildlife as 'good', only for their meat and feel insecure in terms of both quality of life and food insecurity and this sense of insecurity may exacerbate HWC (Murombedzi, 1999). The situation is exacerbated by insufficient revenue from wildlife to the community resulting in decreased tolerance levels from communities towards wildlife and the public or private owners in charge of their management (Mombeshora \& LeBel 2009; Mupamhadzi et al., 2009). This attitude is highlighting a new dimension, the existence of a Social Carrying Capacity (SCC) which measures the sensitivity of local human populations to the presence of wildlife (McGinnis, 2008). The SCC names the Wildlife Acceptance Capacity (WAC: Decker \& Purdy, 1988) as the population size of a species that the human community is willing to tolerate; it is a very subjective measure which needs to be taken into-account in HWC mitigation strategies (Woodroffe et al., 2005).

The negative attitudes of humans towards wildlife impact (Struhsaker, 1997) can become engrained in the minds of many people (Kock, 2003). For example, in Mbire district of Zimbabwe it has been reported that baboons and monkeys 'steal' food from people's houses, raid crops, 'destroy' granaries, kill small livestock like chickens and yet, both do not have any perceived value to locals (Samu, 2010). In other parts of the country, baboons and monkeys draw 'sympathy' from locals who associate them with autochthonous spirits which are believed to bring rainfall. Ethnicity plays a big part in shaping local attitudes towards wildlife. In Zimbabwe, wildlife areas are characterised by ethnic mosaics resulting from settlement patterns that were created by the colonial regime between 1950 and the late 1970s. For example, in the South East Lowveld (SEL) of Zimbabwe, people of different ethnic origins were forcibly moved from their areas and settled in these areas following creation of white owned large scale commercial farms (Mombeshora \& LeBel, 2009). These ethnic groups pursue diverse livelihoods. For example, Shangaan people living in the SEL predominantly rear livestock while the Karanga and Ndebele ethnic groups prefer crop production. Most Shangaan people do not like the idea of living with wildlife because the latter attack their livestock, compete with livestock for forage and sometimes spread diseases to livestock. On the other hand, the Karanga and Ndebele peoples dislike wildlife because some wild animals raid crop fields. Similarly, in Mbire district the Karanga people who recently moved into the area grow cereals and cotton, and the Doma people, who are indigenous to the area and are traditional hunter-gatherers, only value wildlife as meat (Dzingirai, 1999). Linked to the above, landowners and users and even wildlife managers still sometimes deliberately kill wildlife they consider a threat with the view of reducing the problem or exterminating the problem animals species from their neighbourhood (Kock, 2003). 
Some societies also advocate for the total eradication of lions which are viewed as useless and largely responsible for killing people and their livestock. Such views have contributed to the setting up of Problem Animal Control (PAC) programmes in CAMPFIRE (Communal Areas Management Programme for Indigenous Resources) areas of Zimbabwe. PAC entails killing or capturing of problem animals by officials from National Parks. However, people living in Campfire areas often complain about the way PACs are handled. Officials are often blamed for responding too late, especially during the offhunting season or when the problem animal does not have a high trophy value. The manner in which PAC and Campfire dividends are handled by officials helps in creating negative attitudes towards wildlife by local people. An ongoing study being implemented by the Centre for Applied Social Sciences (CASS - UZ, Zimbabwe) has documented cases where locals in the South East Lowveld (SEL) have negative attitudes towards Campfire and wildlife in general. Local communities indicated that they have not received dividends from Campfire proceeds over the last ten years. Local authorities, especially rural district councils (RDCs) have been blamed for withholding proceeds from Campfire. This is understandable because of the hardships RDCs have been facing during the inflationary environment from 2004 to 2009.

\subsection{Mitigation measures}

Human-wildlife conflict is a complex problem, requiring a combination of approaches to manage the conflict (Fig. 25), including wildlife barriers, protecting property, traditional methods and removal of the specific problem animals (Nelson et al., 2003; WWF-SARPO, 2005; LaGrange, 2006; Parker et al., 2007; FAO, 2009). For any human-wildlife conflict management strategy to succeed, it must be sustainable and is therefore ideally administered by the local community itself (WWF-SARPO, 2005).

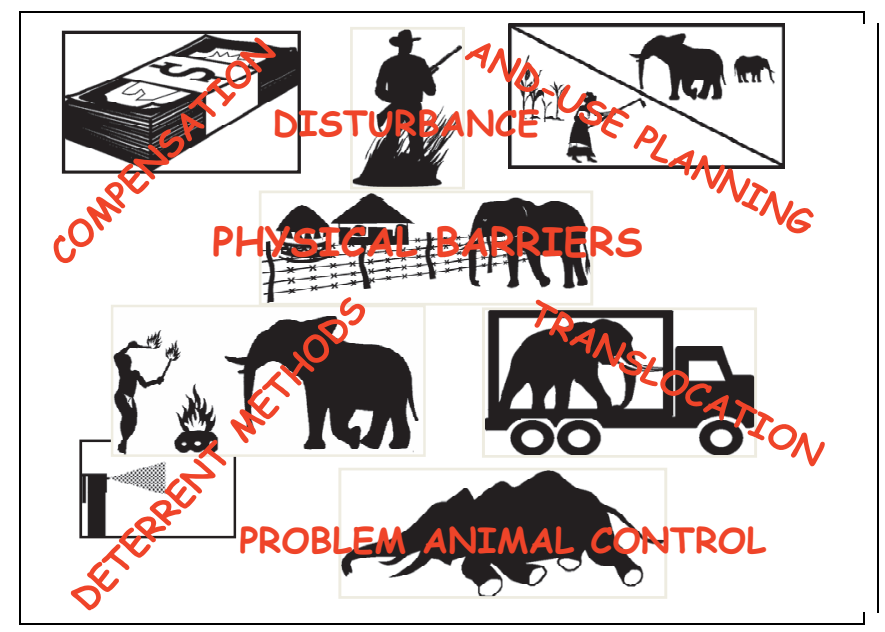

Fig. 25. Mitigation tools for HWC

Farmers' groups have been trained to use non-lethal methods, separated into three separate categories (Osborn \& Parker, 2002; WWF-SARPO, 2005), including vigilance methods aimed at alerting farmers to the presence of approaching wildlife, and passive 
methods aimed at impeding the passage of potential crop-raiding animals using simple physical barriers and deterrents. The third method, an active one, is implemented to scare-off intruders using various forms of disturbance measures such as fires, noisemakers and chemical deterrents.

Most respondents of the Zimbabwean study were not satisfied with the response of local authorities to incidents of human wildlife conflict. In Mozambique, while farmers are deploying a range of solutions, game scouts are monitoring and killing rather than trying to prevent. In this regard, measures of PAC may need to be improved as they are presently perceived as unsatisfactory or weak.

\subsection{Ways forwards: A new PAC approach}

A number of initiatives aimed at reducing HWC and its related negative perceptions by humans towards wildlife have been proposed by governments and wildlife authorities and conservation groups (Katerere, 2005). The CAMPFIRE programme launched in Zimbabwe was considered as one of the key initiatives adopted to deal with HWC (Mukamuri et al., 2009). But the failure by Campfire to reduce poaching has led decision makers to suggest construction of buffer zones or erecting fences (Samu, 2010), ensuring, like the south part of the Limpopo National Park, that wildlife areas will not extend into agricultural land and vice versa (Magane et al., 2003). Another suggestion involves settling people away from wildlife areas such as National Parks and other protected areas (Brockington, 2002). However, a study by Brockington \& Igoe (2006) documented failures of such resettlement policies as many villagers would return to graze their livestock as well as to have continual access to the wildlife meat. This finding illustrates the fact that no quick-fix or one-time solution to the problem of HWC exists (Duffy, 2000) and it requires a multipronged approach, a sustained effort and commitment from local residents and officials. In other words, the art of living with this problem is by increasing the human tolerance of wildlife and to decrease the negative interactions with it.

\subsubsection{Learning from disease control}

Based on strategies developed in response to the threat of emerging zoonotic diseases (Fromenty, 2011), we suggest a coping strategy developed by implementing an improvement of HWC data management as this is the backbone of any attempts to control and prevent HWC incidents.

This PACL approach will be based on a system combining Prevention measures, early Alert mechanisms, application of Control solutions with the objective of Learning from past experiences (Fig. 26). The early detection of HWC generates information, which alerts decision makers timeously, therefore allowing a quick and adequate reaction to control dangerous animals. By providing a complete set of explanatory variables, the flow of information will feed the HWC database. The analysis of it will help to improve the understanding of HWC incidents and improve their mitigation by targeted prevention campaigns. This last point is crucial if we are aiming to reduce the global prevalence of HWC. Previous studies have demonstrated that an adequate prevention campaign, enhancement of early warning and guarding efforts on previously raided farms can reduce incidents of crop raiding by $90 \%$ (Sitatai et al., 2005). The monitoring of this cycle will aid and improve the learning from past experience. 


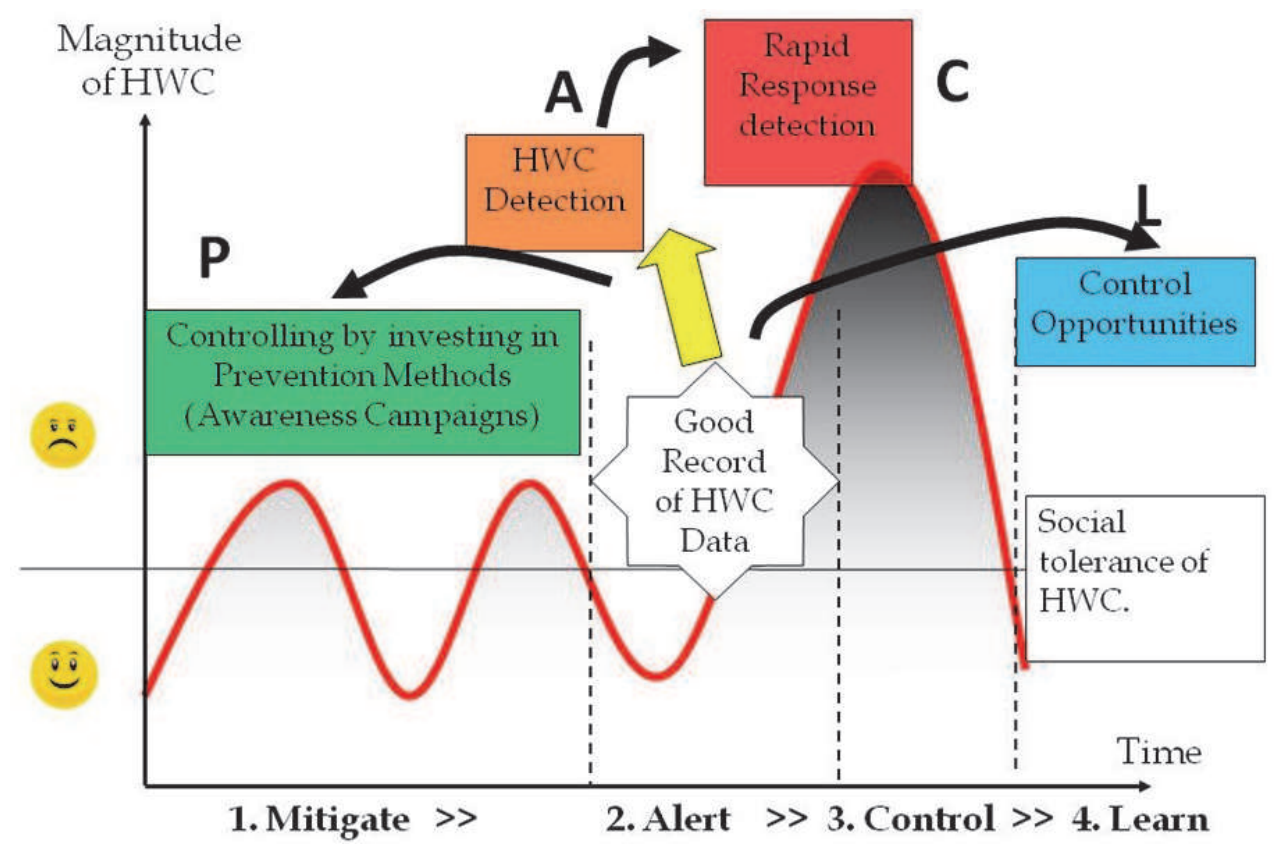

Fig. 26. A new PACL approach

\subsubsection{Alerting and controlling in time}

Monitoring of HWC and conflict mitigation measures has been weak to date, with unclear policies and lack of appropriate responses, this being largely the responsibility of wildlife authorities. Two initiatives are currently developed to address this gap. The first one is a user-friendly educational, management tool, named Management Oriented Monitoring System (MOMS) which was successfully developed in Namibia and introduced in Zimbabwe to monitor illegal offtake in the South East Lowveld of Zimbabwe. This tool, utilized for HWC monitoring in Namibia, allows immediately visualization of the consequences of certain management decisions which makes them also an excellent tool for conflict avoidance or mitigation involving stakeholders and decision makers (Stuart-Hill et al., 2005).

The second one is adding value on the latter in facilitating a quick flow of information, so reducing delays of reaction. Providing an immediate, direct, reliable, simple to use and relatively cheap method of data flow, it will inform local decision makers when urgent reactions have to be taken and increment local and national HWC data base. The proposed solution based on the following assumptions is using FrontlineSMS www.frontlinesms.com, free open source software used by a variety of organizations to distribute and collect information via text messages (SMS).

- Game rangers generate the information based on direct assessment of any HWC incident and utilize various means to communicate including mobile phone. 
- The mobile phone is the nearest thing to a computer that anyone has. SMS, which is cheaper than traditional voice calls, is the dominant form of communication.

- From all district offices, game rangers have the ability to access a GSM network and to send and receive SMS.

- The local level of managing the information is either the head quarters of a National Park or local government focal point. The final destination of all HWC information is the National Data Base.

The case of Quirimbas National Park in Mozambique will help to explain how this approach can be implemented (Fig. 27). Data management needs to combine the management of data from Protected Areas by MITUR (Ministry of Tourism) and from non Protected Areas by MINAC (Ministry of Agriculture). The complex flow of information will be eased with FrontlineSMS and the automatic creation of feedback messages to game rangers, and forward messages alerting decision makers, while raw information will feed Park data bases at provincial level by SMS and a national data base by E-mail.

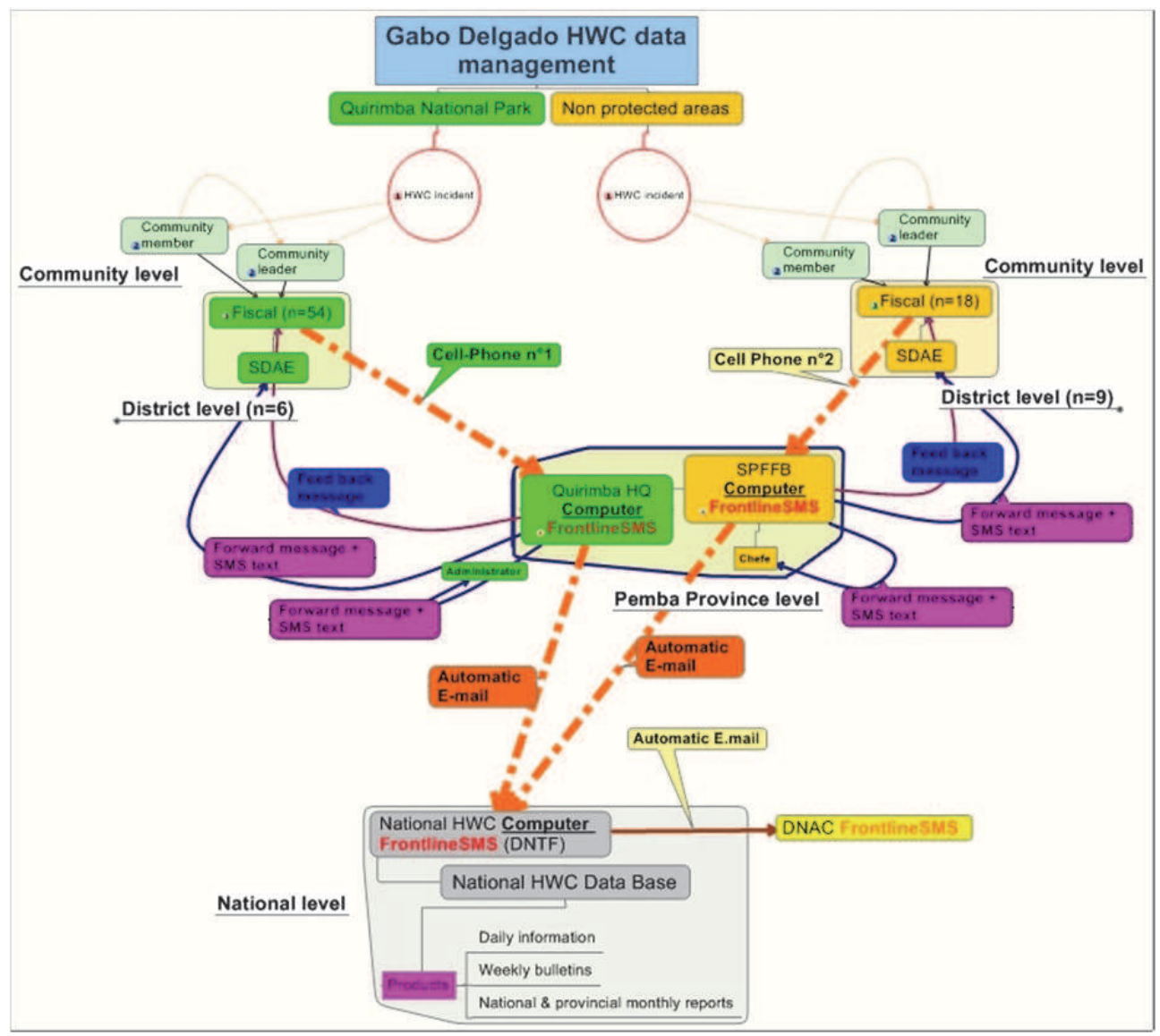

Fig. 27. Theoretical HWC data management in Cabo Delgado Province 


\subsubsection{Investing on prevention measures}

Current methods of managing this conflict have been mostly external, requiring outside intervention, and centralized, requiring authority from a district or central authority. They have been both expensive (use of ammunition, guns, vehicles, etc.) and ineffective (e.g. using firearms to scare-off wildlife). For any HWC management strategy to succeed, it must be sustainable and should therefore be administered by the local community. Mediation and conflict resolution need to take into account the lack of connection between the official framing of conflicts and local responses, efficacy of traditional mechanisms of conflict resolution, competing and contradictory policies, local institutional complexity and its significance to conservation debates and interventions. A number of conservation initiatives aimed at reducing HWC and its related negative perceptions by humans towards wildlife have been proposed by governments, individuals and wildlife authorities have been put into practice with success and failures.

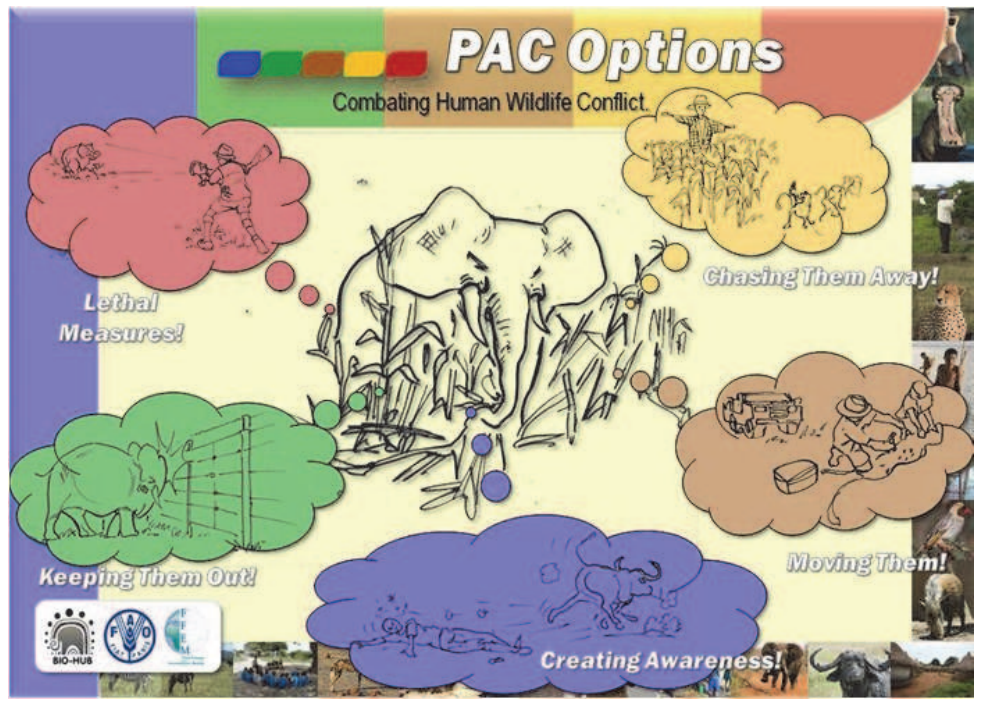

Fig. 28. The PAC options show the different solutions offered from Awareness to Lethal measures

To address some gaps in implementing mitigation measures, BIO-HUB and FAO has recently developed a HWC toolkit. This practical tool, developed for the reinforcement of local capacities, acknowledges that human-wildlife conflict is multifaceted and that some of the mitigation practices proposed to date are ineffective on their own over time. Therefore the toolkit presents tools and practices that can have great success when used in combination (Fig. 28). It is designed not only to help protect people, their livestock and their crops from wild animals, but also to safeguard wild animals from people. The HWC toolkit 


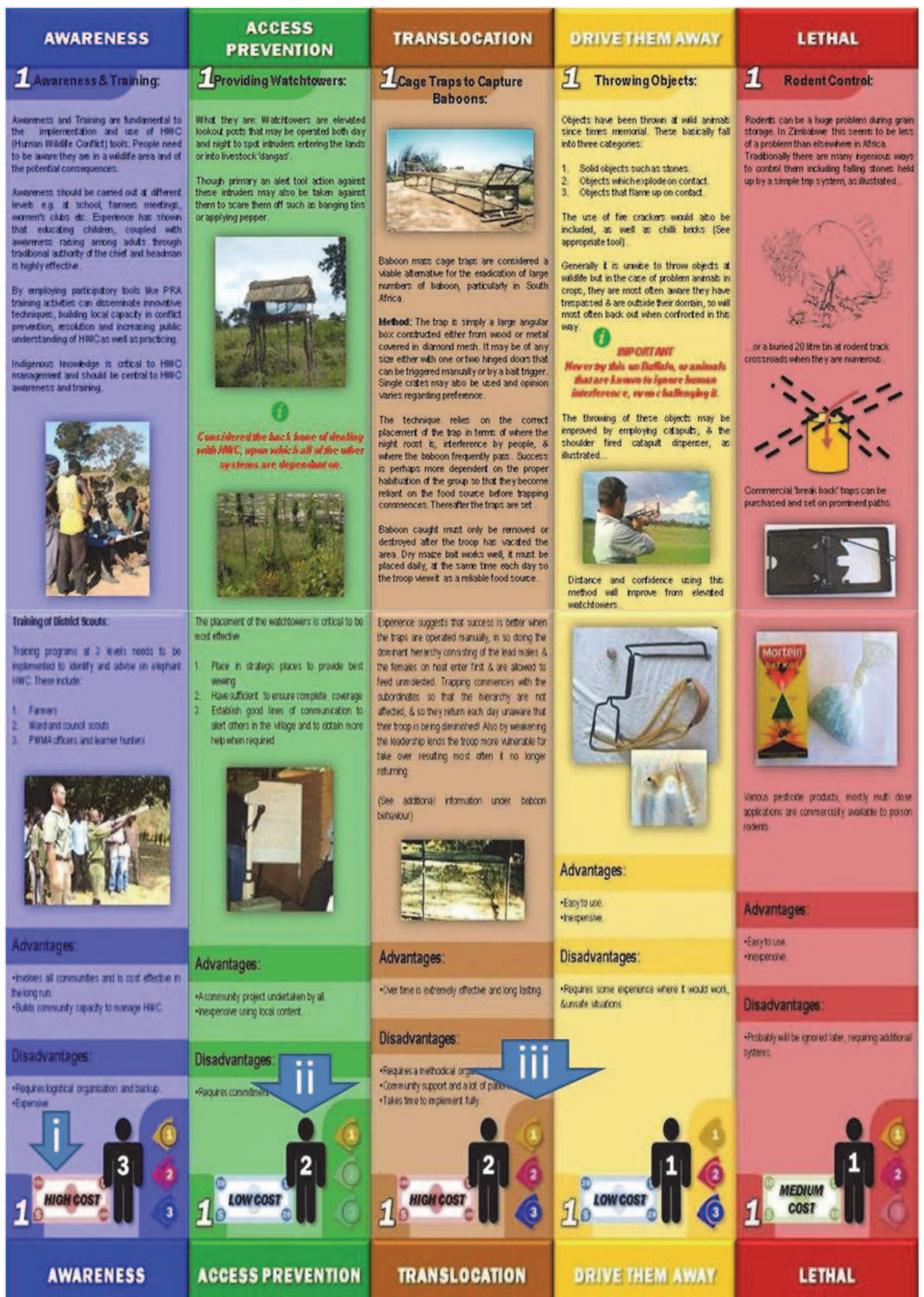

Fig. 29. First set of Tools. Information given at the bottom of each tool indicates (i) cost, (ii) manpower requested or (iii) level of implementation ( $1=$ village, $2=$ district, $3=$ national). 
is designed for use by extensionists working with communities. In addition to presenting tools and practices that can have great success when used in combination, it guides users through HWC situations from incidence to resolution. By intervening in the conflict, a range of solutions become possible using simple to High-Tech devices. The objective is to show that simple and low cost solutions can be implemented at grass root levels before opting for lethal options (LeBel et al., 2010).

Each HWC toolkit is divided in 8 different sections: a Manual indicates how to use the toolkit. The Policy section summarizes what measures are allowed according to the national wildlife legislation which will vary between countries. The Reporting section teaches the recording of HWC incidents. The Environment booklet looks at the environmental situation: People, Village, Livestock, River/Waterhole and Crops/Fields, as the main areas of conflict. In each situation, the toolkit highlights factors of risks linked to human activities. The Wildlife booklet examines sixteen animals (predators, big and small herbivorous, birds, etc) considered predominant in HWC. Understanding the behaviour of each animal helps to pinpoint potential conflicts and gauge requirements for mitigation measures. A combination of tools is put forward for mitigation in 5 colour-coded categories (awareness, access prevention, translocation, driving animals away and lethal control). The Tools section is the largest with more than 90 solutions proposed to reduce and control HWC incidents. Clear explanation is given on how to implement the control options in the five colour-coded categories (Fig. 29).

\section{Conclusion}

Even with low game density, HWC has a significant social and economic impact on communities living at the edge of Protected Areas and it is inevitable that HWC on the one side will increase with the free movement and growing populations of wildlife species in Southern Africa while on the other, the increasing demand for land for agriculture. This is even most evident in respect to elephant populations that have the ability to double in numbers within 15 years. If this situation is not addressed, so that humans and wildlife coexist, wildlife as a natural resource will be condemned to survive only in fenced protected areas.

In an attempt to improve the situation, we suggest an approach based on three pillars:

1. Appreciating the wildlife-domestic interface demands the knowledge of how wildlife move and utilize their home range in comparison to the use of this land for agriculture and wildlife perception by communities living there. Records of HWC activity documented using simple technology such as SMS will help to monitor this interface while determining the dynamics and magnitude of the problem.

2. Minimizing the negative impact of wildlife has to be based on the understanding of animal behaviour. The dissemination and utilisation of the HWC toolkit in its different versions will help communities to be more sympathetic and adopt less riskless attitude when confronting dangerous animals. Also it enables target intervention of specific problem animals through the concept of 'memory fences' to facilitate wild animals respecting human activities and settlement (e.g. discipline of crop raiding elephant employing chilli pepper).

3. Improving community tolerance toward wildlife must start by capacitating the local communities to protect themselves. Building on existing traditional approaches through the HWC toolkit will promote a range of applicable solutions adaptable to their situation. Promoting and improving wildlife based-revenue ventures are considered essential to provide for long term mitigation and human-wildlife coexistence. 


\section{References}

Ministério da Agricultura (2009). Informe Sobre a implentaçao da Estratégia de Gestao de Conflito Homem-Fauna Bravia, de Janeiro a Dezembro de 2009.

Anderson, J. and Pariela, F. (2005). Strategies to mitigate human-wildlife conflicts in Mozambique. Wildlife Management Working Paper $n^{\circ} 8, \mathrm{FAO}$, Rome.

Araman, A. (2009). Human-Elephant Conflict in Northern Mozambique. Human Wildlife Conflict Training of Trainers Workshop, BIO-HUB, Harare: 14.

Barnes, J.I.T. (1998). Wildlife conservation and utilizations. Complements to Southern Africa development. DEA Research Discussion Paper 27. Windhoek, Namibia: 18.

Blanc, J.J., Barnes, R. F. W., Craig, G. C., Douglas-Hamilton, I., Dublin, H. T., Hart, J. A. and Thouless, C. R. (2005). Changes in elephant numbers in major savanna populations in eastern and southern Africa. Pachyderm, Vol. 38, 19-28.

Blanc, J.J., Barnes, R., Craig, G.C., Dublin, H.T., Thouless, C.R., Douglas-Hamilton, I. and Hart, J.A. (2007). African Elephant Status Report 2007: An Update from the African Elephant Database. Occasional Paper Series of the IUCN Species Survival Commission $N^{\circ} 33$. IUCN/SSC. African Ele. Spe. Group. IUCN Gland, Switzerland, 276 pages. : 276.

Breitenmoser, U., Angst, C., Landry, J.M., Breitenmoser-Würsten, C., Linnell, J.D.C. and Weber, J.M. (2005). Non-lethal techniques for reducing depredation. People and Wildlife. Conflict or Coexistence? S. T. A. R. Rosie Woodroffe. Cambridge, Cambridge University Press. 9: 49-71.

BRL ingénerie (2006). Development of the Limpopo National Park and its Support Zone: Feasibility study Draft Report. DBSA, AFD, Ministry of Tourism of Mozambique, Nepad Project Proposal and Feasibility Fund: 291.

Brockington, D. (2002). Fortress conservation. The preservation of the Mkomazi game reserve Tanzania. Oxford London.

Campfire Programme (2007). PAC statistics 2002-2006. Harare, Zimbabwe, Campfire Association.

Cumming, D. and Jones, B. (2005). Elephants in Southern Africa: Management issues and options. WWF-SARPO Occasional Paper.

Decker, D. J. and Purdy, K. G. (1988). Toward a concept of wildlife acceptance capacity in widllife management. Wildlife Society Bulletin 16(1): 53-57.

Distefano, E. (2004). Human-Wildlife Conflict worldwide: collection of case studies, analysis of management strategies and good practices. FAO: 30.

Duffy, R. (2000). Killing for conservation: Wildlife policy in Zimbabwe. Oxford, James Currey.

Dzingirai, V. (1999). Human migration and natural resources management in communal lands: the case of Binga in Zimbabwe: CASS. Harare, University of Zimbabwe. DPhil.

Food and Agriculture Organization (FAO) (2009). Human-wildlife conflict in Africa: causes, consequences and management strategies. Rome, FAO.

Fromenty, P. (2011). From forecasting to control of zoonotic diseases - Linking animal and human systems. OIE Global Conference on Wildlife Animal Heallth and Biodiversity Preparing the Future. . Paris (France). Page 22.

Hulme, D. and Murphre, M. Eds. (2001). African wildlife and livelihoods .The promise and performance of community conservation. Oxford. James Currey. 
International Livestock Research Institute (ILRI) (2009). Climate livestock and poverty challenges at the interface. C. R. 2008-9. Nairobi, Kenya, International Livestock research Institute.

Katerere, J. (1997). Parks without peace. International Parks without peace conference on trans-boundary protected areas as a vehicle for international co-operation, Somerset West, South Africa.

Kock, R. A. (2003). What is the famous wildlife disease interface? A review of current knowledge for the African continent. South and East African experts panel on designing successful conservation and development interventions at the wildlife /livestock interface and humans health (AHEAD) forum IUCN 5TH world parks conference, Durban, South Africa.

LaGrange, M. (2006). The Capture, Care and Management of Wildlife. Pretoria, South Africa, Van Schaik.

Lamarque, F. (2010). Memorandum of the consultancy mission carried out in Maputo, Mozambique by Francois Lamarque, Program Officer - IGF Foundation. IGF/FAO: 7.

LeBel, S., Mapuvire, G. and Czudek, R. (2010). Human-Wildlife Conflict Toolkit: comprehensive solutions for farmers and communities. Unasylva 236(61): 12-13.

Magane, S., Soto, B., Munthali, S., Schneider, M., Vicente, G., van Wyk, A., Nhalidede, A., Rode, P., Grossman, D., Holden, P., Kleibl, T. and Maluleke, L. (2003). Limpopo National Park: Management \& Development Plan. F. Edition, Ministerio Do Turismo, Direcçao Nacional de Areas de Conservaçao: 96.

McGinnis (2008). Background on Urban Deer Management. Grand Haven, Urban Deer Management Plan: 5.

McGregor, J. (2005). Crocodile crimes: people versus wildlife and the politics of postcolonial conservation on Lake Kariba, Zimbabwe. Geoforum 36: 353-369.

Mizutani, F., Muthiani, E., Kristjanson, P. and Recke, H. (2005). Impact and value of wildlife in pastoral livestock production in Kenya .Possibilities for health ecosystem conservation and development for the poor. South and East experts panel on designing successful conservation and development interventions in the wildlife/livestock interface and human health(AHEAD) forum IUCN 5TH world parks conference, Durban, South Africa.

Mombeshora, S. and Le Bel, S. (2009). "Parks-people conflicts: the case of Gonarezhou National Park and the Chitsa community in south-east Zimbabwe." Biodivers Conserv 18: 2601-2623.

Mukamuri, B. B., Manjengwa, J. M. and Anstey, S. (2009 ). Beyond proprietorship :Murphree laws on community based natural resources management in Southern Africa. Harare, Weaver press.

Mupamhadzi, I. T., Matema, C. and Muvengwi, J. (2009). Observations and Informal Findings on Wild Meat Trade: Socio-economic research with local communities in and around the Save Valley Conservancy, Zimbabwe. Harare, PARSEL Project: 32.

Murombedzi, J. (1999). Capacity Building: The Theoretical Relevance and Practical Importance to the Development of Common Property Institutions for Management of Natural Resources: A Southern African Perspective. A paper presented on a workshop on Proceedings of Regional Natural Resource Management, Johannesburg, South Africa.

Murphree, M. J. (2005). Counting sheep. The comparative advantages of wildlife and livestock, a community perspective. South and East African experts panel on designing e 
successful conservation and development interventions at the wildlife /livestock interface and human health (AHEAD) forum. 5th world parks conference, Durban South Africa, IUCN.

Nelson, A., Bidwell, P. and Sillero-Zubiri, C. (2003). A review of human-elephant conflict management strategies. P. W. Initiative. Oxford University, Wildlife Conservation Research Unit: 25.

Osborn, F. V. and Parker, G. E. (2002). Living with elephants II: A manual for implementing an integrated program to reduce crop loss to elephants and to improve livelihood security of small-scale farmers. Mid Zambezi Elephant Project.

Parker, G. E., Osborn, F. V., Hoare, R. E., and Niskanen, L. S. (2007). Human Elephant Conflict Mitigation: A Training Course for Community-Based Approaches in Africa. Trainer's Manual. Livingstone Zambia \& Nairobi Kenya, Elephant Pepper Development Trust \& IUCN/ AfESG.

Samu, N. (2010). Securing farming systems and livelihoods in communal lands adjacent protected areas through human wildlife conflict management. CASS. Harare, University of Zimbabwe. Masters Degree thesis.

Sitatai, N. W., Walpole, M. J. and Leader-Williams, N. (2005). Factors affecting susceptibility of farms to crop raiding by African elephants: using a predictive model to mitigate conflict. Journal of Applied Ecology 42: 1175-1182.

Steinfeld, H., Gerber, P., Wassenaar T. D. and Castelet, V. (2006). Livestock long shadow. Environmental issues and options, FAO.

Struhsaker, T. T. (1997). Ecology of an African rainforest: Logging in Kibale and the Conflict between Conservation and Exploitation. Univ. Press of Florida, Gainesville.

Stuart-Hill, G., Diggle, R. , Munali, B., Tagg, J. and Ward, D. (2005). The Event Book System: a community-based natural resource monitoring system from Namibia. Biodiversity and Conservation 14: 2611-2631.

Whyte, I. J. and W. Swanepol (2006). An aerial census of the Shingwedzi Basin area of the Parque Nacional do Limpopo (Limpopo National Park) in Mozambique. Scientific Report 02/2006, South African National Park.

Woodburne, S., Prangley, A. and Mabuza, L.M. (2002). Socio-economic, Demographic, land-use and Attitudinal Survey of the communities residing in the Singuedzi River Bassin, Limpopo National Park, Gaza Province, Mozambique. Peace Park Foundation, Ministry of Tourism: 201.

Woodroffe, R., S. Thirgood and Rabinowitz, A. (2005). The impact of human-wildlife conflict on natural systems. People and Wildlife. Conflict or Coexistence? S. T. A. R. Rosie Woodroffe. Cambridge, Cambridge University Press. 9: 1-12.

World Wide Fund for Nature Southern Africa Regional Programme Office (WWF-SARPO) (2005). Human wildlife conflict manual. Harare, Zimbabwe, WWF-SARPO. 


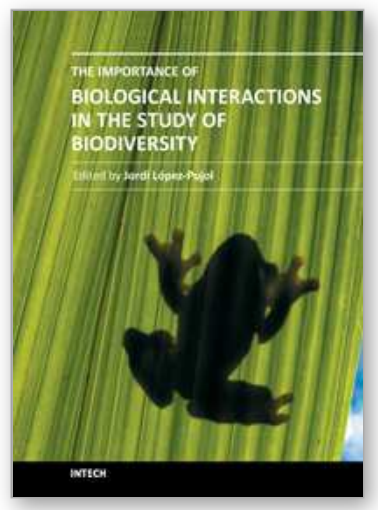

\section{The Importance of Biological Interactions in the Study of Biodiversity}

Edited by Dr. Jordi LÃ $\tilde{\beta}^{3}$ ez-Pujol

ISBN 978-953-307-751-2

Hard cover, 390 pages

Publisher InTech

Published online 22, September, 2011

Published in print edition September, 2011

The term biodiversity defines not only all the variety of life in the Earth but also their complex interactions. Under the current scenario of biodiversity loss, and in order to preserve it, it is essential to achieve a deep understanding on all the aspects related to the biological interactions, including their functioning and significance. This volume contains several contributions (nineteen in total) that illustrate the state of the art of the academic research in the field of biological interactions in its widest sense; that is, not only the interactions between living organisms are considered, but also those between living organisms and abiotic elements of the environment as well as those between living organisms and the humans.

\section{How to reference}

In order to correctly reference this scholarly work, feel free to copy and paste the following:

Sébastien Le Bel, Amon Murwira, Billy Mukamuri, René Czudek, Russell Taylor and Mike La Grange (2011). Human Wildlife Conflicts in Southern Africa: Riding the Whirl Wind in Mozambique and in Zimbabwe, The Importance of Biological Interactions in the Study of Biodiversity, Dr. Jordi LÃ ${ }^{3}$ pez-Pujol (Ed.), ISBN: 978-953307-751-2, InTech, Available from: http://www.intechopen.com/books/the-importance-of-biologicalinteractions-in-the-study-of-biodiversity/human-wildlife-conflicts-in-southern-africa-riding-the-whirl-wind-inmozambique-and-in-zimbabwe

\section{INTECH}

open science | open minds

\author{
InTech Europe \\ University Campus STeP Ri \\ Slavka Krautzeka 83/A \\ 51000 Rijeka, Croatia \\ Phone: +385 (51) 770447 \\ Fax: +385 (51) 686166 \\ www.intechopen.com
}

\author{
InTech China \\ Unit 405, Office Block, Hotel Equatorial Shanghai \\ No.65, Yan An Road (West), Shanghai, 200040, China \\ 中国上海市延安西路65号上海国际贵都大饭店办公楼 405 单元 \\ Phone: +86-21-62489820 \\ Fax: $+86-21-62489821$
}


(C) 2011 The Author(s). Licensee IntechOpen. This chapter is distributed under the terms of the Creative Commons Attribution-NonCommercialShareAlike-3.0 License, which permits use, distribution and reproduction for non-commercial purposes, provided the original is properly cited and derivative works building on this content are distributed under the same license. 